Article

\title{
Building a Super Smart Nation: Scenario Analysis and Framework of Essential Stakeholders, Characteristics, Pillars, and Challenges
}

\author{
Murali Krishna Penmetsa ${ }^{1, * \mathbb{D}}$ and Sebastian Juan Bruque Camara ${ }^{2}$ \\ 1 School of Computer Science and Information Technology, Lucerne University of Applied Sciences and Arts, \\ 6343 Rotkreuz, Switzerland \\ 2 Department of Business Organization, Marketing and Sociology, University of Jaén, 23071 Jaen, Spain; \\ sbruque@ujaen.es \\ * Correspondence: krishna.penmetsa@hslu.ch; Tel.: +41-78-342-3868
}

Citation: Penmetsa, M.K.; Bruque Camara, S.J. Building a Super Smart Nation: Scenario Analysis and Framework of Essential Stakeholders, Characteristics, Pillars, and Challenges. Sustainability 2022, 14, 2757. https://doi.org/10.3390/ su14052757

Academic Editors: Sandro Serpa,

Carlos Miguel Ferreira

and Maria José Sá

Received: 9 February 2022

Accepted: 24 February 2022

Published: 26 February 2022

Publisher's Note: MDPI stays neutral with regard to jurisdictional claims in published maps and institutional affiliations.

Copyright: (c) 2022 by the authors. Licensee MDPI, Basel, Switzerland. This article is an open access article distributed under the terms and conditions of the Creative Commons Attribution (CC BY) license (https:/ / creativecommons.org/licenses/by/ $4.0 /)$.

\begin{abstract}
Globally, countries are increasingly facing challenges regarding their national future post the COVID-19 pandemic with respect to decreasing and aging populations; dwindling workforces; trade wars due to restricted movement of goods, people, and services; and overcoming economic development and societal problems. Accordingly, we identify the challenges and corresponding solutions that act as pillars for a framework to build a super smart nation. We analyze 73 peerreviewed research papers from Scopus index databases and use the Delphi methodology to identify the challenges, which include people and society, robots, technology, research and innovation, digital infrastructure, data, politics, governance, and sustainability. Further, we discuss the relevant solutions, including top leadership motivation and commitment; proactive steps from the government, development of policies; legal frameworks and laws; creation of awareness programs; use of advanced technologies (such as robotics and semantic technologies); and development of interoperable infrastructure; innovation ecosystem; sustainable energy sources; and global standards for education system through transformation of the education system. These novel insights have valuable practical and theoretical implications for guiding policymakers, industry leaders, and researchers in building a super smart nation.
\end{abstract}

Keywords: Delphi methodology; digital nation; smart city; smart nation; super smart society; society 5.0

\section{Introduction}

Countries across the globe are currently facing new and unprecedented challenges to their national future post the COVID-19 pandemic. The pandemic crisis is revealing the present strengths and weaknesses of countries' local governments based on their decisions regarding closing national borders for domestic and international travel, mobilizing the healthcare infrastructure immediately, and integrating and streamlining digital infrastructure. Moreover, nations globally are facing megatrends, such as demographic changes, shifts in global economic power, urbanization, natural resource scarcity, climate change, and technological disruption.

Market research organizations and governmental research bodies try to predict the next election's outcome, economic growth rates, or futuristic trends for the following years. Furthermore, developed nations, such as Japan, Singapore, Estonia, and countries in the European Union, have started taking radical national transformational steps toward building people-centric super smart societies to overcome future economic development challenges and societal problems and enable free movement of goods, people, and services to facilitate living, doing business, offering public services, and enhancing international cooperation at the national, continental, and global levels. Long-term planning will help nations to forecast future challenges and take radical transformation steps toward facing 
them, as in the case of the COVID-19 pandemic crisis and the trade wars. Therefore, it is crucial to assess the future growth challenges and the requirements for transforming nations in a sustainable manner that pre-empts future socio-economic developmental and societal problems. To do so, nations must contemplate these issues right now and use the projected figures on the population in 2035, the present population, and the proportion of the population that will retire, among others, to forecast and prepare for the future. Although this information is readily available for national governments, nations fail to take appropriate steps toward long-term planning. Furthermore, achieving this desirable future depends on the futuristic thinking of national leadership, vision, common goals, mission, political stability, stakeholder involvement, and the actions of national governments.

According to the Population Reference Bureau [1], the current world population is 7837 million and is predicted to increase to 8847 million in 2035 and 9688 million in 2050. Furthermore, $19 \%$ of Europe's population is above 65 years, whereas $3 \%$ and $9 \%$ of African and Asian populations, respectively, are above 65 years. The same segment of the population is also expected to increase in Europe by 2035 and 2050, raising more concerns about the decline in the size of the workforce, increase in social security costs, socio-economic development, and other social problems. Moreover, the percentage of the population aged less than 15 years in Europe is 16\%, whereas the global average is $26 \%$ ( $41 \%$ in Africa and $24 \%$ in Asia), raising concerns about insufficient workforce in the future.

Sustainable development and global transformation are the main targets of the United Nations' 2030 Agenda to strengthen universal peace-a plan for people, planet, and prosperity. To eliminate global poverty and address the challenges of sustainable development, all countries and stakeholders need to implement this plan through international cooperation. Furthermore, its vision is to ensure global access to the highest quality of education at all levels. Countries around the globe are facing tremendous challenges in areas such as the digital divide, access to digital infrastructure, access to online and mobile technologies, income levels, climate change, and technology when it comes to sustainable development, leading to a rise in inequality within and between countries. However, the advent of information and communication technologies, global interconnectivity, and scientific and technological innovation in a wide range of fields, such as medicine and energy, present tremendous opportunities. It is now easier for people to gain access to education than before. We can accelerate human progress, bridge the digital divide, and develop knowledge societies. All national targets should be formulated in line with global ambition while taking local circumstances into consideration. Sustainable development must be considered in conjunction with other relevant ongoing processes in the economic, social, and environmental spheres.

Furthermore, the revised agenda of the United Nations calls for national policies for sustainable, inclusive, and inclusive economic growth. Moreover, regional and subregional integration, as well as interconnectedness among regional economic zones, are crucial for sustainable development. In the process of achieving sustainable development, each country is confronted with specific challenges. A special emphasis should be given to the most vulnerable countries, including African countries, the least developed countries, landlocked developing countries, and small island developing states. Further, to ensure that no one is left behind, quality education, health, and well-being should be prioritized. To achieve sustainable and inclusive economic growth, which are essential for prosperity, income inequality and wealth sharing should be addressed. Societies must be dynamic, resilient, innovative, and people-centered. Countries need to adopt policies that promote sustainable industrial development; universal access to reliable, affordable, and modern energy services; and high-quality and resilient infrastructure. The implementation plan of each country will determine the country's economic and social development.

The process of digital transformation [2] has changed drastically since the COVID-19 pandemic began, and various national stakeholders have started to understand the benefits of digitalization. Hence, nations, governments, and lawmakers should shape nations toward building people-centric super smart societies based on the concepts of smart nation 
and super smart society to improve people's living standards and boost the economic development of nations. This will ensure that nobody is left behind, that is, with regard to sustainable economic growth, and address future social problems in developed, emerging, and developing nations. However, digitalization in developed, emerging, or developing economies depends on several factors such as the education system, awareness, people and society, technologies, adoption of technology, research and innovation ecosystem, digital infrastructure, political leadership, laws, regulatory frameworks and policies, and proactive measures from government and international cooperation with nations, among others.

Holroyd [3], taking Japan as a case study, states that a super smart society is still in the initial phases of development, and it is an innovative governmental initiative developed in response to the 3/11 earthquake and tsunami and futuristic challenges regarding the ageing population, low birth rate, shrinking labor force, and the increasing costs for social security and healthcare. Super smart societies cannot develop naturally; rather, nations must co-create them by involving relevant stakeholders and using advanced technologies. However, research on building super smart nations is in its nascent stage; research on building super smart nations remains scarce, and only a few published frameworks are available. Thus, we identify the following research questions to address the gaps in the literature.

1 What are the characteristics of and who are the stakeholders in building a super smart nation?

2 What are the challenges and pillars for nations in building a super smart nation?

Additionally, we integrate the three key stakeholders of a smart nation, namely, government, companies, and people, which could be helpful for developing a super smart nation and building a relevant framework by identifying the stakeholders, characteristics, pillars, and challenges for building a more people-centric society. The primary motivation of this study is to construct a robust framework for building a super smart nation to overcome future challenges such as a pandemic crisis; decreasing population and workforce; increasing social security and healthcare costs; and restricted movement of goods, people, and services to boost economic development and solve societal problems. The framework may help us better understand the megatrends, stakeholders, characteristics, pillars, challenges, and rationales that are pivotal to the success of super smart nations globally.

The remainder of this paper is structured as follows. The Background section presents the theoretical background information on the concept of super smart nations and the relevant stakeholders, characteristics, pillars, and challenges; the Methodology section describes the Delphi methodology used in this study; it is followed by the Results section. The next section presents the discussion, and finally, we have the Conclusion section.

\section{Background}

A super smart nation is a concept that can be built by analyzing the super smart society [4] and smart nations [5,6]. These concepts can be considered intermediate steps toward building a super smart nation based on centralized and decentralized governance structures. Additionally, super smart nations must adopt the theories developed to create a society that is people-centric and super smart (also called society 5.0).

In addition, Sá et al. [7] state that a super smart society offers technological development to solve social challenges and build a sustainable society. According to Potočan et al. [8], the super smart society vision includes incorporating advanced technologies such as artificial intelligence (AI), big data, blockchain, Internet of things, robots, and virtual reality in all industries and social activities to achieve economic development and solve social problems to accomplish the United Nations' Sustainable Development Goals (SDG's). On the one hand, according to Nair et al. [9], a super smart society is a concept whereby nations start to visualize AI and robots taking over human jobs to improve the quality of life of stakeholders [10] and solve challenges that arise from the declining birth rate and workforce as well as the increasing social security costs of healthcare. On the other hand, according to Holroyd [3], nations must co-create super smart societies by involving relevant stakeholders and using advanced technologies, as they do not develop naturally. According 
to Mavrodieva and Shaw [4], a super smart society's main characteristics include cities, energy, disaster recovery, healthcare, agriculture, supply chain, manufacturing, finance, insurance, and public services. According to Gurjanov et al. [11], a super smart society comprises health care, social safety, life activity safety, energy, education, comfortable environment, transportation, industry 4.0, and meal provision safety. Furthermore, a smart city is characterized by a smart economy, as well as smart people, smart governance, smart mobility, smart environment, and smart living [12-15].

A smart nation is a concept in which all urban and rural citizens, governments, and businesses live in a smart society with semi automation, to improve public services, mobility, trade and business, and living standards with high efficiency. It addresses challenges by taking a whole-nation approach for the ease of living, doing business, and availing public services. Furthermore, smart nations are intended to resolve endemic urban problems, such as ageing, energy crises, pollution, safety, and crime using advanced technologies. One way to achieve this is through e-residency, which opens digital borders to anyone, anywhere $[14,16-20]$ through decentralized techno-governance for doing business and smart governance for offering better public services. It enables sustainable development and free movement of work without spatial and geographical barriers. It ensures sustainable development and free movement of workers without spatial or geographical limitations. Further, its mission is to foster innovation in the fields of online governance, cybercrime, and the development of the information society. A smart nation involves the transformation of governance from centralized to decentralized, and smart cities [12-15] or digital nations can be seen as intermediate steps.

However, this is presently only a feasible solution for developed and less populated nations, such as Singapore, Estonia, and Luxembourg. The Singapore Smart Nation and Digital Government Office views digital government, digital business, and digital society as the building blocks of a smart nation. Furthermore, Estonia can also be considered a smart nation. Before the COVID-19 pandemic, Estonia built one of the world's most advanced smart and information societies, providing services like electronic voting, online education in schools, and electronic government. A defining characteristic of Estonia is its digital identity, accessible services, and secure data exchange via the X-Road, where Estonians retain full ownership of their data. Further, Deloitte reports that Luxembourg is also working towards becoming a smart nation because of its small size, lack of natural resources, and geographical location, in addition to other unique sets of challenges. To maintain its competitive position and address global trends and shifts, it is continuously developing its capabilities and competencies. A key component of Luxembourg's pursuit of becoming a smart nation is its emphasis on six pillars, namely technology and infrastructure, data, skills, and competencies, innovation culture, and public-private ecosystems.

Smart cities [12-15] and Digital nations [21] can be seen as intermediate steps toward a smart nation, transforming governance from being centralized towards being more decentralized. Smart cities in smart nations are characterized by six main features: smart economy, smart people, smart governance, smart mobility, smart environment, and smart living. Every citizen, business, and government institution must accelerate digitalization and create smart societies. Moreover, smart cities have faced numerous challenges related to people, technology, politics, governance, economics, and sustainability. Further, IMDSUTD [22] has developed a Smart city index that measures residents' perceptions of the available resources in their city, such as structures and technology. Overall, the rankings range from 1 to 118, and they are evaluated in five key areas: health and safety, mobility, activities, opportunities, and governance. Singapore is ranked first, Zurich is second, and Oslo is third on the index. Switzerland had three cities in the top 10, with Lausanne, Geneva, and Zurich ranked 5th, 8th, and 10th, respectively.

The super smart nation comprises the government, companies, and people as its three key stakeholders. In addition, all such innovative solutions require full support, participation, and cooperation from citizens and the international community's support through dialogue. Therefore, this concept is cogent on participation by all members of 
society [23]. However, this new concept requires an ecosystem for digital transformation. To execute such plans, it is essential to understand the stakeholders, characteristics, pillars, and challenges relevant to building a nation. A literature review on digital and smart nation helped to identify smart nation's stakeholders (i.e., government, companies, and people) and characteristics such as smart economy, smart people, smart governance, smart mobility, smart environment, and smart living. The literature review on digital nations and smart nations and the results from this study help categorize the challenges of building a super smart nation into 10 categories (see Appendix A Table A1): (1) people and society, (2) robots, (3) technology, (4) research and innovation, (5) digital infrastructure, (6) data, (7) politics, (8) governance, (9) economics and business, and (10) sustainability.

The three key stakeholders and the above-mentioned characteristics can be considered foundational building blocks for developing a super smart nation, and every citizen, business, government, and public institution (such as universities) plays a vital role in accelerating digitalization and building this new concept. Here, the government should act as a facilitator by creating an environment that engenders more research and innovation along with more investments wherever necessary, bringing all three stakeholders together to create a road map for the rest of the world and create a modern nation through the development of super smart nation concepts.

\section{Materials and Methods}

This study attempts to gather more information on the characteristics of a super smart nation through a literature review. In addition, scenario planning techniques based on the Delphi methodology [24-30] are used to identify the possible challenges and solutions in building a super smart nation.

The literature review helped in developing the questionnaire for two to three rounds of interviews [24]. We limited the Delphi rounds to a maximum of three rounds, through consensus [24] approach, to choose the study variables for identifying the challenges, which were conducted from 21 June 2021 until 25 July 2021. The experts were asked to select the challenges for super smart nations by agreeing or disagreeing on a seven-point Likert scale $(1=$ strongly disagree and 7 = strongly agree). All mean values from the expert study with a value of five or less were deleted to measure the consensus approach. The Delphi research methodology is based on an established process [28] and comprises six stages: (1) developing projections, (2) questionnaire development, (3) inviting experts, (4) first round of questionnaire, (5) second round of study and feedback, and (6) third round of questionnaire and feedback. Figure 1 illustrates the Delphi research methodology used in this study.

\subsection{Developing Projections}

The year 2035 is chosen as the target year for the scenario planning as it is far enough into the future to forecast the future challenges and solutions nations may have due to the increasing older population, decreasing birth rate and workforce, urbanization, technology disruption, trade wars, and socio-economic and societal problems. Additionally, longterm planning helps nations take steps to achieve their objectives. As part of the research methodology process, a questionnaire is required to identify the stakeholders, characteristics, pillars, and challenges concerning building a super smart nation. Accordingly, one of the first steps is identifying the variables for the challenges that influence the development of a super smart nation and grouping them into different categories of solutions (pillars).

We conducted a search using the Emerald and Scopus databases to identify the study variables. This helped us gather interdisciplinary and relevant results published since 2016. Finally, we identified 73 relevant research papers, and two researchers engaged in the review to identify the variables. Keywords such as smart cities, smart nations, digital nations, and super smart societies were used to gather relevant research papers to identify and group the stakeholders, characteristics, and challenges into broad categories such as people and society, robots, technology, research and innovation, digital infrastructure, data, 
politics, governance, economics and business, and sustainability (see Appendix A Table A1) to develop a questionnaire for the study.

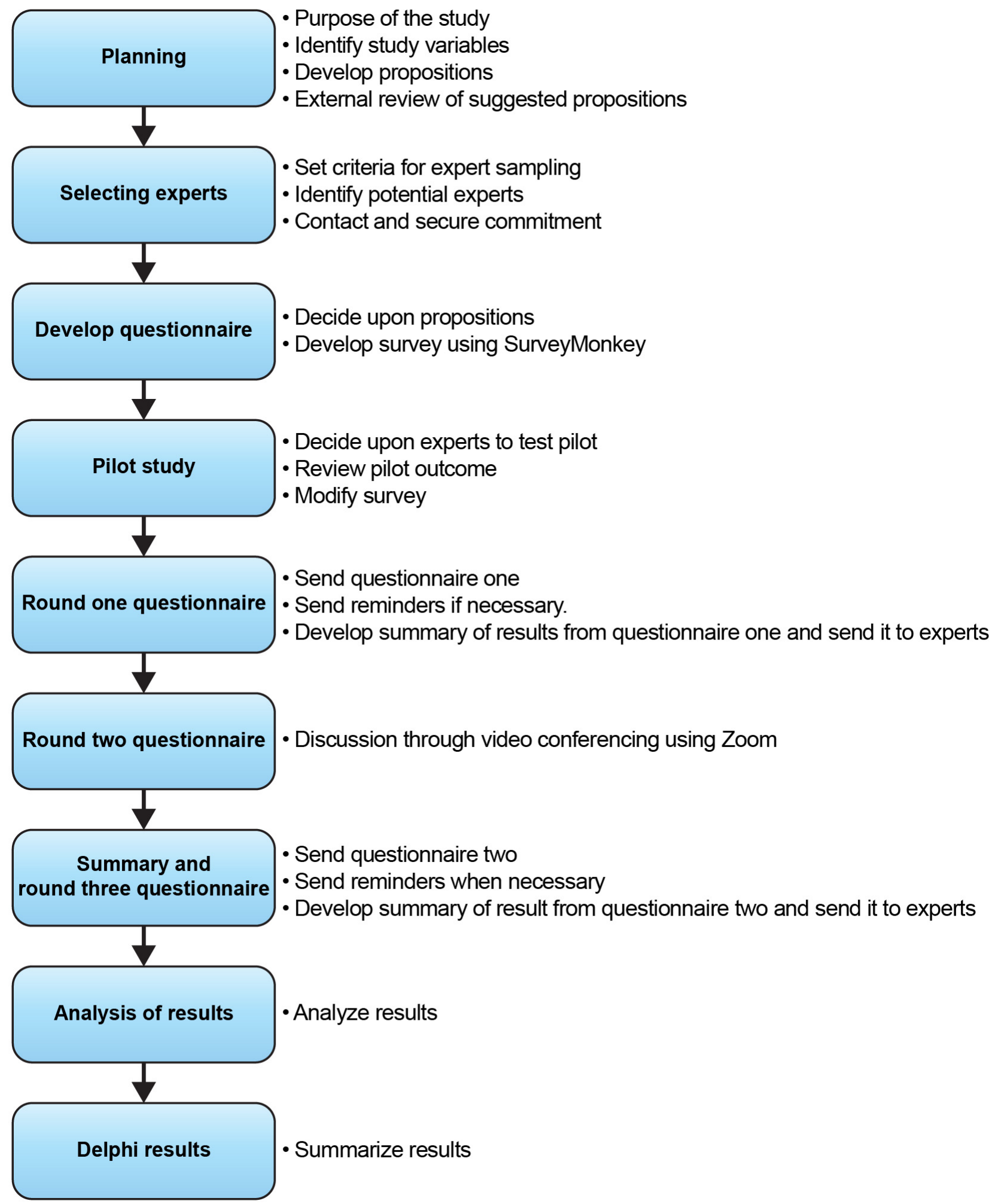

Figure 1. Delphi research methodology process. Source: The authors' work, based on the research by Melander et al. [28]. 


\subsection{Questionnaire Development}

Based on the findings of the literature review, the most important variables and questionnaire were discussed with four experts with experience in digital transformation, super smart societies, digital nations, smart nations, and smart cities. In addition, a web-based study along with Zoom discussions with experts was identified as an efficient methodology for this study. After developing the questionnaire (see Supplementary Materials), a pilot study was conducted by sending the questionnaire to three subject matter experts. As part of the web-based study, the participants were given an introduction page with instructions, a page to share background information regarding their industry and years of experience, followed by one question per page. In addition, for each projection, the experts had the option to answer on a 7-point Likert scale $(1=$ strongly disagree and $7=$ strongly agree $)$.

\subsection{Inviting Experts}

We selected experts (see Appendix A Table A2) from nine nationalities to obtain a broader study perspective and have listed research papers' corresponding authors as referees and experts in this area. We contacted several experts through email and phone calls to ask if they are interested in participating in the study. We also contacted several experts to provide background information on the study through email with a PowerPoint presentation copy about stakeholders; characteristics; pillars; challenges; and clear instructions, timelines, and mutually beneficial cooperation proposals to work together in the long term. In addition, the experts were informed about the kind of support that is required from them, how much time is needed for study participation, and how the information shared will be used. In total, 12 experts agreed to participate in the Delphi study. To obtain the best output for the analysis in a timely manner, several best practices were followed to improve the participation of experts, namely, clearly explaining the process and timelines, limiting the study to short online questionnaires followed by interactive Zoom sessions, sharing short updates on study progress and next steps, staying in touch with experts, and providing feedback regarding participation in the study.

\subsection{First Round of the Questionnaire}

The 12 experts who expressed interest in participating in the study were sent an automated personalized message and URL link to answer the study using the SurveyMonkey tool. We maintained the anonymity of each participant, and each participant's details were linked to the study link connected to the expert's email address. Accordingly, the experts were reassured of the privacy and security of the personal details that they share. The experts were given a period of 1 week to complete the first round of the study. After 5 days, a gentle reminder email was sent to participants who had not yet participated in the study. After 1 week, the study was closed, and the findings were shared with all the experts the following day. Then, based on the results, the reviewers of this study changed the choices in the questionnaire for additional variables and made the necessary adaptations with experts' inputs for further rounds of the study.

\subsection{Second Round of the Questionnaire}

Based on the results of the first round, the mean values of variables with a score of five or less than five were dropped to facilitate the consensus approach. Then, 11 experts were interviewed through Zoom for approximately $90 \mathrm{~min}$ each, and the discussions were recorded. One of the 12 experts dropped out due to health reasons. The second round of the study mainly focused on the solutions for overcoming the challenges identified and shortlisted via the consensus approach in the first round. Moreover, we ensure that the time gap between the two Delphi rounds did not exceed 1 week. Thus, experts' knowledge and availability of time was not affected, and we had a higher response rate. 


\subsection{Third Round of the Questionnaire}

In the final round, only 10 experts answered the online study sent via the SurveyMonkey tool. This round focused on challenges wherein some of the experts gave suggestions for additional challenges in round one. The experts had 1 week to complete this round. After 5 days, a gentle reminder email was sent to experts who had not yet participated in the study. After 1 week, the study was closed, and the findings were collected and shared with all the experts.

\section{Results}

In this section, we describe the results of the stakeholders, characteristics, pillars, and challenges from online studies and expert interviews, and outline a framework for building a super smart nation. The challenges for super smart nations are classified into 10 broad categories: people and society, robots, technology, digital infrastructure, data, research and innovation, politics, governance, economics and business, and sustainability (see Table 1). The extant research categories of smart cities [31,32], smart nations, and digital nations, are further subcategorized without focusing on robots, research and innovation, data, and educational institutions. Since relevant research is unavailable, the challenge categories provide the basis for building a framework for developing super smart nations. The remainder of this section discusses each challenge, its pillars, and the framework.

Table 1. Key challenges associated with building super smart nations.

\begin{tabular}{|c|c|c|c|}
\hline Categories & Challenges to Building Super Smart Nations & Mean & Standard Deviation \\
\hline \multirow{8}{*}{ People and Society } & Digital literacy and divide (PS1) & 6 & 0.95 \\
\hline & Changing nature of work (PS2) & 6 & 0.58 \\
\hline & Poverty (PS3) & 5.83 & 1.14 \\
\hline & Social and economic disparities (PS4) & 5.75 & 0.83 \\
\hline & Aging population (PS5) & 5.58 & 0.64 \\
\hline & $\begin{array}{l}\text { Generation divide (Difference of opinions between younger } \\
\text { people, their parents and grandparents) (PS6) }\end{array}$ & 5.4 & 0.80 \\
\hline & Lack of citizen participation (PS7) & 5.25 & 1.09 \\
\hline & Decreasing work force (PS8) & 5.08 & 1.19 \\
\hline \multirow{5}{*}{ Robots } & Education and training to work with robots (R1) & 5.82 & 1.11 \\
\hline & Safety (R2) & 5.8 & 0.75 \\
\hline & Evolution of organizational workflows (R3) & 5.42 & 1.04 \\
\hline & $\begin{array}{l}\text { Privacy and trust in a human-robot co-working environment } \\
\text { (R4) }\end{array}$ & 5.42 & 1.50 \\
\hline & Acceptance of robots in workplace (R5) & 5.25 & 1.36 \\
\hline \multirow{7}{*}{ Technology } & Interoperability (T1) & 5.92 & 0.95 \\
\hline & Lack of user-friendly applications (T2) & 5.92 & 1.11 \\
\hline & Lack of technical support (T3) & 5.67 & 1.03 \\
\hline & System integration (T4) & 5.58 & 1.32 \\
\hline & Access to latest technologies (T5) & 5.5 & 1.26 \\
\hline & Lack of data availability (T6) & 5.33 & 1.18 \\
\hline & Information technology standards (T7) & 5.25 & 1.09 \\
\hline
\end{tabular}


Table 1. Cont.

\begin{tabular}{|c|c|c|c|}
\hline Categories & Challenges to Building Super Smart Nations & Mean & Standard Deviation \\
\hline \multirow{7}{*}{ Research and Innovation } & Lack of funding (RI1) & 6 & 0.82 \\
\hline & Education system (RI2) & 5.92 & 1.19 \\
\hline & Focus on research and development on new technologies (RI3) & 5.75 & 1.09 \\
\hline & Research on smart applications (RI4) & 5.7 & 0.78 \\
\hline & Innovation ecosystem (RI5) & 5.67 & 1.11 \\
\hline & Investment in disruptive technologies (RI6) & 5.58 & 1.11 \\
\hline & Increased cost of research and development (RI7) & 5.42 & 1.38 \\
\hline \multirow{9}{*}{ Digital Infrastructure } & Security and privacy (DI1) & 6.25 & 0.83 \\
\hline & Power reliability (DI2) & 6 & 1.10 \\
\hline & Internet reliability (DI3) & 5.9 & 1.14 \\
\hline & Lack of interactive public services (DI4) & 5.67 & 0.94 \\
\hline & Poor data availability and scalability (DI5) & 5.67 & 1.11 \\
\hline & Lack of internet connectivity (DI6) & 5.42 & 1.38 \\
\hline & System failures (DI7) & 5.33 & 1.03 \\
\hline & Lack of network and telecommunication infrastructure (DI8) & 5.25 & 1.30 \\
\hline & Lack of access to computer and technologies (DI9) & 5.17 & 1.14 \\
\hline \multirow{7}{*}{ Data } & Security (D1) & 6.9 & 0.30 \\
\hline & $\begin{array}{c}\text { Veracity (Managing the data quality, uncertainty, and } \\
\text { trustworthiness of data) (D2) }\end{array}$ & 6.5 & 0.50 \\
\hline & Privacy (D3) & 6.4 & 0.80 \\
\hline & Value (Data is worthless until it is converted into value) (D4) & 6.1 & 0.54 \\
\hline & Velocity (Speed at which data must be analyzed) (D5) & 5.9 & 1.70 \\
\hline & $\begin{array}{l}\text { Human dynamics (Humans' role in data collection, data } \\
\text { analysis and decision making) (D6) }\end{array}$ & 5.5 & 1.36 \\
\hline & Volume (Huge amount of data) (D7) & 5.5 & 1.14 \\
\hline \multirow{10}{*}{ Politics } & Political cooperation between countries (P1) & 6.5 & 0.50 \\
\hline & Political leadership (P2) & 6.5 & 0.67 \\
\hline & Political stability (P3) & 6.17 & 0.69 \\
\hline & Common goals, vision, and mission (P4) & 6.08 & 1.04 \\
\hline & Lack of government support (P5) & 5.92 & 0.95 \\
\hline & Lack of governance and trust (P6) & 5.92 & 1.50 \\
\hline & Coordination, collaboration, and consultation (P7) & 5.67 & 1.25 \\
\hline & Corruption (P8) & 5.5 & 1.19 \\
\hline & Lack of investment (P9) & 5.33 & 1.18 \\
\hline & Lack of public-private partnership (P10) & 5.17 & 1.46 \\
\hline \multirow{5}{*}{ Governance } & Lack of regulatory frameworks and policies (G1) & 6.25 & 0.92 \\
\hline & Lack of transparency (G2) & 6.17 & 0.90 \\
\hline & Lack of accountability (G3) & 6 & 1.29 \\
\hline & Lack of standardization (G4) & 5.83 & 0.80 \\
\hline & Lack of stringent civil and criminal law (G5) & 5.58 & 1.44 \\
\hline
\end{tabular}


Table 1. Cont.

\begin{tabular}{|c|c|c|c|}
\hline Categories & Challenges to Building Super Smart Nations & Mean & Standard Deviation \\
\hline & Ethical practices (G6) & 5.5 & 1.43 \\
\hline & Culture (G7) & 5.08 & 1.04 \\
\hline \multirow{5}{*}{ Economics and Business } & Know how in use of smart applications for business (EB1) & 5.7 & 1.27 \\
\hline & Lack of financial resources (EB2) & 5.33 & 1.31 \\
\hline & Lack of sustainable revenue (EB3) & 5.33 & 0.75 \\
\hline & Lack of budget for operational and maintenance costs (EB4) & 5.17 & 0.99 \\
\hline & Lack of laws and regulatory frameworks (EB5) & 6.8 & 0.40 \\
\hline \multirow{4}{*}{ Sustainability } & Lack of innovation integrated education system (S1) & 6.4 & 0.92 \\
\hline & Lack of sufficient natural resources (S2) & 5.6 & 1.36 \\
\hline & Lack of energy efficient devices (S3) & 5.5 & 0.92 \\
\hline & Lack of energy supply (S4) & 5.08 & 1.38 \\
\hline
\end{tabular}

\subsection{Stakeholders}

To identify the stakeholders of building super-smart nations, we used the stakeholders identified in the literature review for digital and smart nations for questionnaire preparation and the Delphi research methodology process with experts through online studies to corroborate the findings. We identified three stakeholders-people, companies, and government-from the three Delphi rounds, with respect to building a super-smart nation by 2035 .

\subsection{Characteristics}

To identify the characteristics of building super-smart nations, we used the characteristics identified in the literature review for smart cities [33] for questionnaire preparation and the Delphi research methodology process with experts through online studies to corroborate the findings. We identified six stakeholders-smart economy, smart people, smart governance, smart mobility, smart environment, and smart living-from the three Delphi rounds.

\subsection{Challenges}

To identify the challenges of building super smart nations, we incorporated the challenges (see Appendix A, Table A1) identified in the literature review for smart cities [32,34-38], digital nation characteristics [39], and smart nations [5] for questionnaire preparation. Following this, we used the Delphi method to conduct online studies and interviews with a panel of experts. Additionally, the experts were asked to add to the list of challenges if they felt anything was missing. Finally, we identified 68 challenges from the three Delphi rounds. We also identified the mean scores and standard deviations of the challenges faced in building a super smart nation (Table 1). Challenges with a score of five or a mean value of less than five were dropped.

The identified challenges are grouped into 10 categories to develop appropriate categories or new categories of challenges. The experts' inputs helped us to identify 68 challenges in 10 broad categories (Table 1).

\subsection{Pillars}

In this subsection, we grouped the solutions identified from the analysis of the challenges into 11 categories including people and society, educational institutions, robots, technology, research and innovation, digital infrastructure, data, politics, governance, economics and business, and sustainability. If these categories are strengthened, they may be 
further categorized as pillars. The remainder of this subsection discusses each pillar of the identified challenges.

\subsubsection{People and Society}

One pillar for building a super smart nation is the people and society as they manage the technology. As is notable in Figure 2, discussions with the experts reveal that creating more awareness and confidence is a solution for building a super smart nation. After analyzing the data, we group the relevant solutions suggested by experts under the people and society pillar.

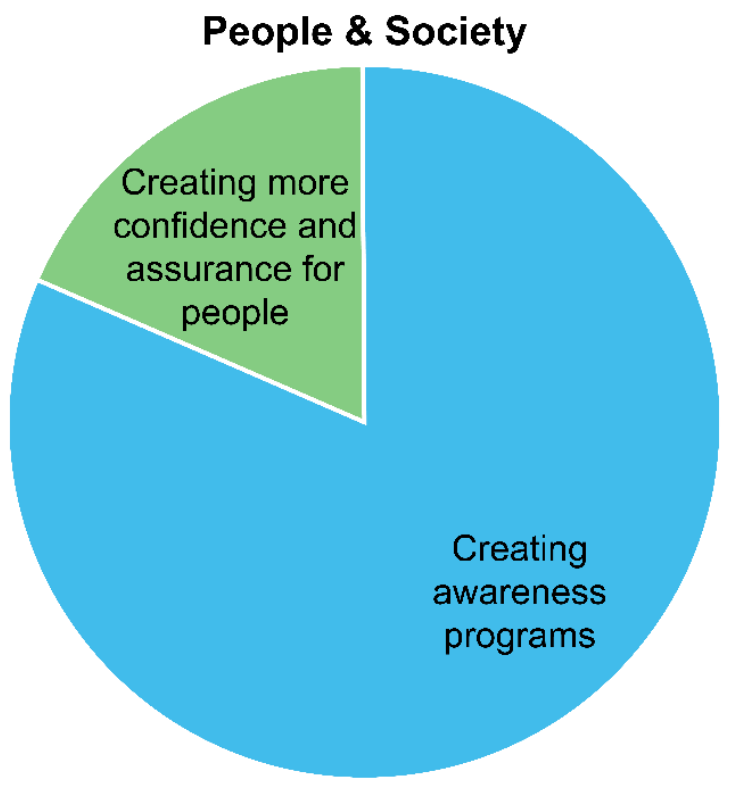

Figure 2. Key solutions associated with people and society for building a super smart nation. Source: Authors' work, based on analysis of study results.

\section{Creating Awareness Programs}

According to respondent R3, creating more awareness programs using promotional channels, such as media using celebrities and society influencers, can help to motivate people to learn how to use technology and make everyone aware of digitalization. Furthermore, R2 expresses that creating more awareness programs on cybersecurity threats to young students at the gymnasium level, like what has been done in Denmark, can be viewed as a solution. R5 also expresses that identifying the segments of people who are digitally illiterate, visiting their homes, and helping them understand the benefits of using technology by educating them can be viewed as practical steps. Similarly, R1 states that countries must develop a specific policy to go out and find homeless people, create devices that are easier for the elderly to see and use, and give free digital devices to the poor.

Likewise, R8 states that creation of awareness programs about the benefits of robotics and automation and making older people understand the positive benefits of robots is necessary. R8 and R11 express that people and employees can take advantage of working for fewer hours than before by utilizing robots for less productive activities; having more social and personal life with a family can help to change the perception of people towards the use of robots. Additionally, R6, R12, R7, and R2 mention creating awareness of what robots can and cannot do, safety benefits for working for a longer duration of time, increasing efficiency by doing some activities in a shorter time than humans, and creating more confidence for humans in integrating humans and robots to work together, respectively. Further, R4 and R7 state that there is a need to create awareness among employees in organizations that they will not lose their jobs, will be rewarded with more value-adding activities, and further explain to them that change management is a lifelong learning process 
in organizations, making them accept the benefits of using technology and highlight the need for organizations to move forward with lifelong learning by upskilling to perform activities better and accepting robots in the workplace.

\section{Creating More Confidence and Assurance for People}

R8 mentions creating more confidence among people that they will be educated and trained how to use robots at work, so that people start to accept robots at work. Moreover, R7 states that educating citizens about successful use cases in Japan and similar countries would be very helpful. Similarly, R3 and R7 express that creation of more confidence and assurance among humans that robots are not going to replace humans, the work activities of robots will be integrated with those of humans, and an environment to enhance human skills will be provided, along with proactive measures by the government developing policies to increase confidence and remove insecurity perception toward robots will be very helpful.

\subsubsection{Educational Institutions}

Another pillar for building a super smart nation is educational institutions. The analysis of the data from the experts shows that the need for education and training is considered a solution to building super smart nations. After analyzing the data, we group all the relevant solutions suggested by experts under the educational institution pillar.

\section{Education and Training}

Discussions with R11 and R12 reveal a need to transform the education system as in Finland and South Korea, and develop long-term strategies and policies as in Estonia, by teaching coding in schools to 5-year-olds. Furthermore, R3 and R7 express that developing global uniform education standards to meet industry skill requirements is necessary, as most of the nations' education systems are similar, excluding very few country-specific courses. Moreover, R2 and R3 express that educating students about cybersecurity threats at the primary education level, such as gymnasiums; addressing the steps toward bridging the skills requirement gaps by involving the three stakeholders, that is, students, universities, and companies; and transforming the education system by meeting the expectations of demand and supply through proper education policies and stakeholder alignment can be beneficial initiatives. R4 expresses that encouraging citizens to study by offering free education can be helpful and motivating. In addition, R11 expresses that encouraging online education from top-ranking universities and service providers at reasonable costs would be a beneficial initiative.

\subsubsection{Robots}

Robots are another pillar for building a super smart nation. As observable in Figure 3, the analysis of data from the experts shows that learning from the use cases of successfully adopted technology in countries and the use of advanced technologies, such as robotics and automation, are viewed as solutions for building a super smart nation. After analyzing the data, we group all relevant solutions suggested by experts under the robot pillar.

\section{Learning from Use Cases of Successfully Adopted Robotics in Countries}

The experts state that learning from use cases of successfully adopted robotics in countries is one of the solutions to overcoming this challenge. R5 expresses that it is ideal to start using robots at home and later integrate them into companies to make people understand the benefits of using robots. In addition, R1 states that Japan has been the best example to gain more knowledge on robots and cultural friendliness toward the use of technology and robots for many years. Additionally, R3 states that some schools in Japan have started using robots as teachers, some restaurants have replaced waiters with robots, and homes have started using robots for cleaning purposes as well. Furthermore, R1 mentions that making robots talk like humans and giving them googly eyes would 
make humans more comfortable and facilitates the acceptance of robots in society. Further, R12 expresses that robots can be used in locations where people get injured and automated processes in manufacturing sites.

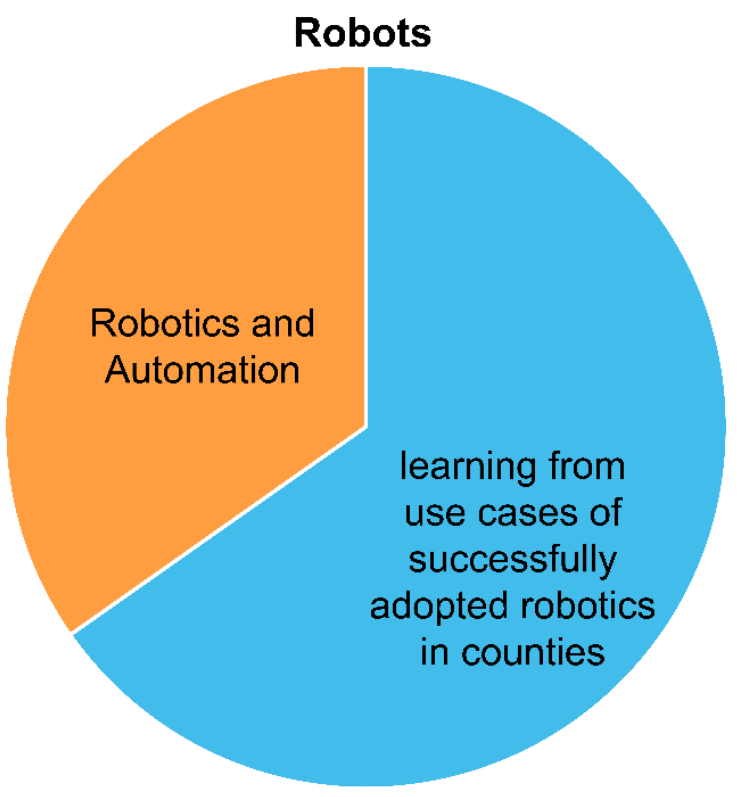

Figure 3. Key solutions associated with robots for building a super smart nation. Source: Authors' work, based on analysis of study results.

Automation and Robotics

Furthermore, R10 and R12 express that automation and the use of robots can help overcome these challenges. One of the best examples to explain automation and the use of robots is the Amazon Go store in America that has no human employees except the people who are managing it. Moreover, the entire checkout is performed automatically with cameras, including refilling the order of new stocks. In conjunction, R2 expresses the need for more research on human-friendly robots and adoption practices, including the challenges that we may encounter when we introduce robots in the human environment and mitigating dangers with regard to safety and security while using robots.

\subsubsection{Technology}

Another pillar for building a super smart nation is technology. As observable in Figure 4, the analysis of this data from the experts shows that the adoption of technology, involvement of the right stakeholders, and development of infrastructure are considered solutions for building a super smart nation. After analyzing the data, we group all relevant solutions suggested by experts under the technology pillar.

\section{Adoption of Technology}

R3, R5, and R8 express that developing user-friendly applications and smart assistance can help people adopt technologies. Accordingly, citizens can ask questions in whatever language they want and use video tutorials to use the technology. Furthermore, R11 states that involving the right stakeholders and building partnerships can be very helpful. Further, R11 goes on to say that public-private partnerships can help develop technologies and digital infrastructure if the government cannot fund the development of technologies, as is the case in Africa. The respondents mention that in some top companies, such as Google, Facebook, and Amazon, revenues are much higher than that of some of the developing nations, and building public-private partnerships for mutual benefit will be helpful. Similarly, R4 expresses that open-source collaboration is an excellent source for software development for people from various countries and regions to collaboratively work together toward common objectives and mutual benefit. 


\section{Technology}

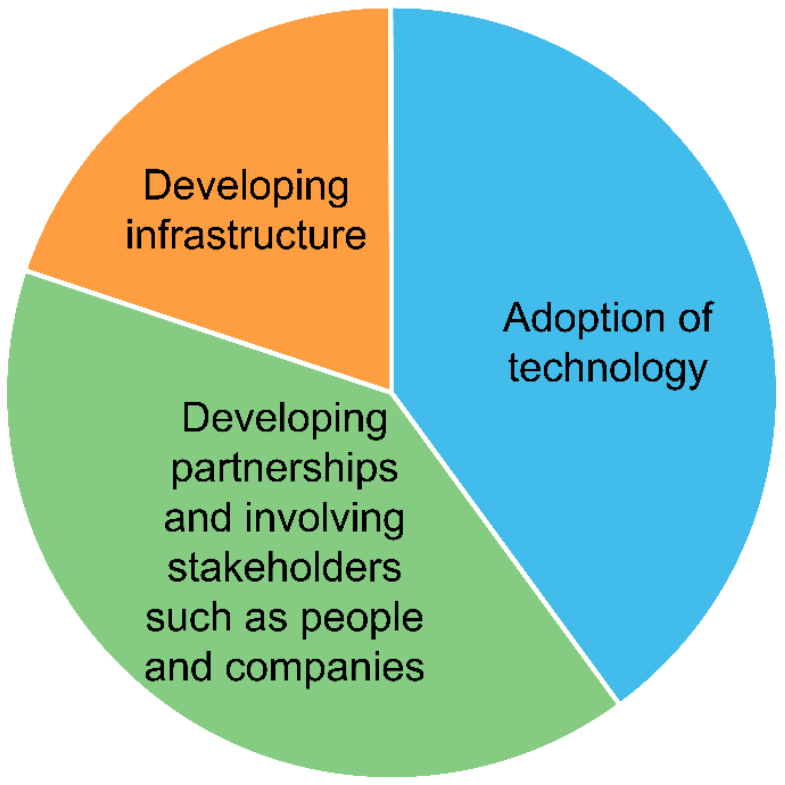

Figure 4. Key solutions associated with technology for building a super smart nation. Source: Authors' work, based on analysis of study results.

Developing Partnerships and Development of Infrastructure

The experts mention that the development of infrastructure is significant for the development of a super smart nation. Giving the example of self-driving cars, R8 states that developing interoperable infrastructure is very important because digital infrastructure must be interoperable with several other technologies such as blockchain, artificial intelligence, and 5G technology, among others. R7 expresses a need for the integration of a single and straightforward platform as interoperability does not currently exist, and we have many passwords for several purposes such as profile, medical, bank, and children's education. This kind of single and simple platform will change the perception and adoption of technology.

\subsubsection{Research and Innovation}

Another pillar for building a super smart nation is research and innovation. As observable in Figure 5, the analysis of this data from the experts shows that creating an innovation-based education system, developing an innovation ecosystem, funding for technology development, and public and private partnerships are solutions for building a super smart nation. After analyzing the data, we group all the relevant solutions suggested by experts under the research and innovation pillar.

\section{Innovation-Based Education System}

R3 mentions that there is a need to develop a global standard for education systems like global standards for mobile phones, the Internet, and cars. It is essential to educate students on case studies suitable for primary schooling with respect to future demands and innovation. People will talk about these technologies and understand their benefits. Moreover, R2 expresses that governments should redesign the education system with project-based education to promote creative skills. The expert mentions that the education system in India is far behind in this respect, and there is a need to address the gap between education at universities and industry requirements with mutual collaboration and cooperation. Furthermore, R8 expresses that the education system should evolve, as most education offered globally is similar except for two courses, namely, geography and history. Moreover, R12 expresses that integrating research-based curricula into the education system can be helpful. In addition, R3 expresses that designing study programs 
and curricula according to industry requirements is essential to finding jobs and avoiding wasting time and money.

\section{Research and Innovation}

\section{Building private and public partnerships}

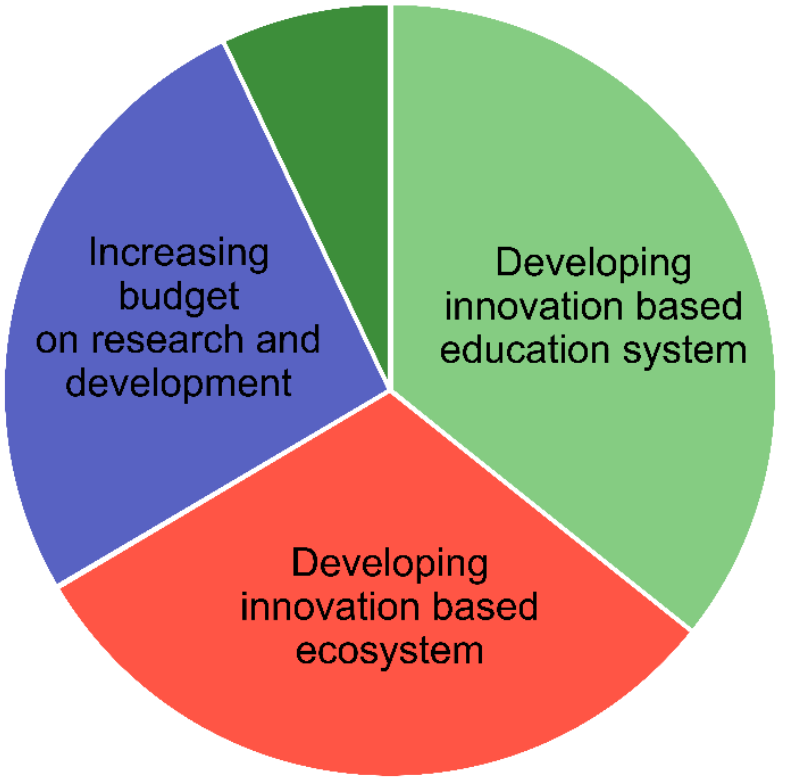

Figure 5. Key solutions associated with research and innovation for building a super smart nation. Source: Authors' work, based on analysis of study results.

Developing Innovation Ecosystem

Experts R1, R2, R4, and R5 express that it is crucial to involve governments, companies, researchers, and citizens to build ecosystems that facilitate research, experiments, and building new technologies. Furthermore, R5 states that building an innovation ecosystem can be done such that students and companies are in the same building and work closely together to solve social problems and resolve smart nations' future challenges. Additionally, R2 mentions that the government needs to increase the budget for research and development, and R3 expresses that companies should collaborate with universities in pursuit of research and development. Finally, R7 states that working on customer-driven innovation is more critical as compared to design-driven innovation to ensure that people buy valuable and helpful things.

Increasing Budget for Research and Development

R2 expresses the need to increase funding for the adoption of technology, as the expenditure incurred by some countries for this purpose is minimal. Moreover, universities and companies must cooperate to overcome national challenges. For example, in Denmark, universities and companies work closely together, which is not the case in India. Therefore, the government must fill this gap by bringing both stakeholders together with appropriate policies. Furthermore, R8 expresses that there is a need for research and development on Internet bandwidth regarding future technologies, such as 6G, as we are all heavily dependent on the Internet. Moreover, R8 goes on to say that research on advancement of blockchain technology is essential for storing our information, and if it is compromised, the whole nation will be in distress. Furthermore, quantum computing, a fast-processing computation method, is in development. Therefore, we need to consider how to make secure data. In addition, R2 expresses that by increasing the technology budget, research on sustainable energy and sustainable development initiatives can help overcome these challenges. 
Private and Public Partnerships

R10 expresses that private and public partnerships are important solutions. Furthermore, R11 states that the top five companies globally can provide services to governments that cannot solve all the problems. Moreover, the respondents express that there is a need for governments to develop regulations and laws to ensure that data are secure and not in the control of big companies in exchange for support extended by top companies. In addition, R6 states that collaboration with relevant stakeholders can help in utilizing the resources actively and catalyzing research on new technologies.

\subsubsection{Digital Infrastructure}

Another pillar for building a super smart nation is digital infrastructure. As observable in Figure 6, the analysis of this data from the experts shows that the use of blockchain technology for security and privacy, accessibility to digital infrastructure, and stakeholders' involvement are solutions for building a super smart nation. After analyzing the data, we group all relevant solutions suggested by experts under the digital infrastructure pillar.

\section{Digital infrastructure}

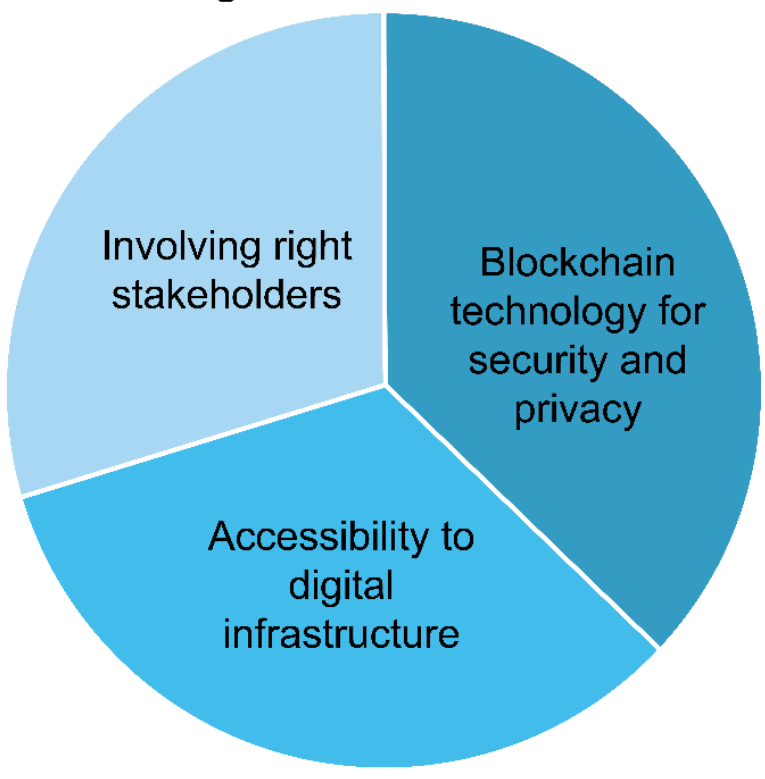

Figure 6. Key solutions associated with digital infrastructure for building a super smart nation. Source: Authors' work, based on analysis of study results.

\section{Blockchain Technology for Security and Privacy}

Experts R3 and R11 express that blockchain technology can be considered a solution for overcoming security and privacy challenges, and R2 states that the underlying mechanism of blockchain is based on cryptography. Furthermore, R12 expresses that blockchain can be used for identity and access management and critical digital infrastructure for accessing healthcare records information. Moreover, giving South Korea as an example, R8 mentions that future Internet technologies based on domain names are helpful in taking measures on security and privacy with regard to digital infrastructure. In addition, R5 expresses that digital infrastructure that uses secure protocols is critical for overcoming the challenges of Internet reliability; even if the Internet goes down, the other parts of the system still function safely and securely.

Accessibility to Digital Infrastructure

Experts state that access to digital infrastructure is crucial. R1 states that national governments' top priority should include building a digital infrastructure, taking inspiration from or following the lead of Central Africa. The steps taken by the governments of these 
nations have helped citizens access banking, retail operations, and political movements using the Internet. Furthermore, R3 states that Internet access, like education, should become a fundamental human right for everyone and be available across all living conditions.

Moreover, R7 expresses that Internet satellite infrastructure (star link) would be a perfect solution to overcome future challenges concerning Internet reliability. In addition, R6 mentions that it is essential to think holistically by considering other interactive devices and systems when developing digital infrastructure. Further, R8 goes on to say that network and telecommunication infrastructure is essential for smart home devices as it is based on the Internet of Things and is connected to other devices (e.g., self-driving cars for transportation). On the one hand, to ensure that everything is ordered, R5 states that a regulatory framework on the reliability of infrastructure is essential (e.g., Chinese telecom equipment used to build 5G infrastructure). On the other hand, R7 expresses that edge computing capabilities are required to analyze data at the edge before the use of cloud or data centers.

\section{Involving Right Stakeholders}

The experts mention that stakeholders' involvement is equally significant. R4 states that the government's topmost priority should be to develop new technologies through the development of public-private partnerships. Furthermore, giving the African partnership model as an example, R11 mentions that public-private partnerships can help overcome the challenges of developing cheaper devices. This model can help overcome the challenge of affordability, and concurrently, companies can offer their services. Moreover, R6 expresses that it is essential to think holistically, and diversity involvement helps obtain feedback from different stakeholders. In addition, R4 states that to overcome the challenges of red tape, such as taking 10 signatures to make decisions to push a file through various departments, it is crucial to bring all 10 stakeholders into one room and then sit for 1 hour to have 10 decision-makers' signatures or opinions. Furthermore, R4 goes on to say that a single-window permission system for foreign direct investors could be a good solution, as this is a working model in some nations.

\subsubsection{Data}

Another pillar for building a super smart nation is data. As observable in Figure 7, the analysis of the experts' responses shows that the use of blockchain technology and advanced technologies can be considered solutions for building a super smart nation. After analyzing the data, we group all relevant solutions suggested by experts under the data pillar.

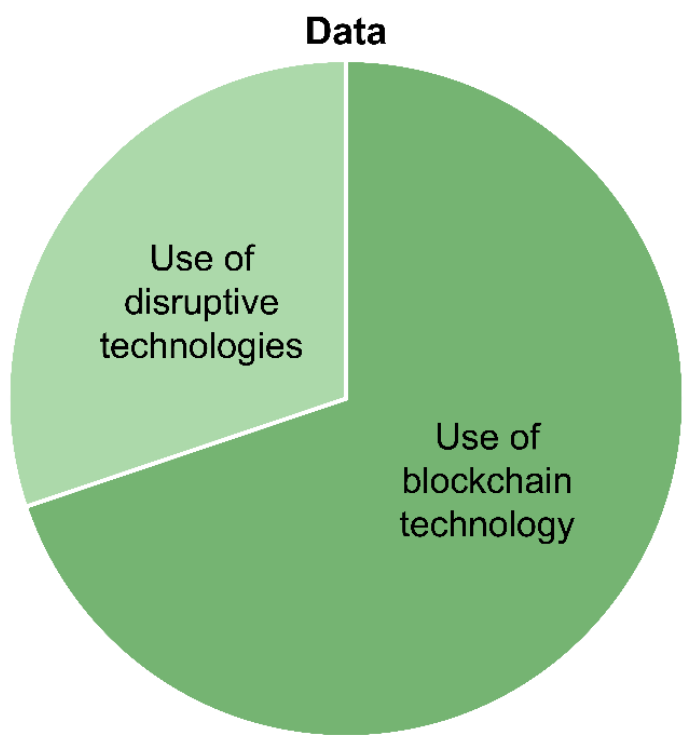

Figure 7. Key solutions associated with data for building a super smart nation. Source: Authors' work, based on analysis of study results. 
Use of Blockchain Technology

Experts R3 and R8 state that blockchain technology is a solution to manage data security and protect data. R5 mentions that compliance by design with the mechanisms of self-sovereign identity can help overcome the above challenges.

\section{Use of Disruptive Technologies}

R2 expresses that big data architecture and new algorithms, such as deep learning and, more importantly, new computing paradigms, such as quantum computing, will help solve data challenges. Moreover, R7 states that faster data processing solutions can be used to secure high volume data, which can also be helpful in identifying value from data and process data at the edge for faster outcomes. In addition, R5 mentions that these semantic technologies can help to provide proactive services. R6 states that standardization could help in the management of data. R11 states that standardization of data types and data processing is necessary.

\subsubsection{Politics}

Another pillar for building a super smart nation is politics. As notable in Figure 8, expert analysis of this data shows that top leadership motivation and commitment, technology, and digital knowledge and skills are solutions for building a super smart nation. After analyzing the data, we group all the relevant solutions suggested by experts under the politics pillar.

\section{Politics}

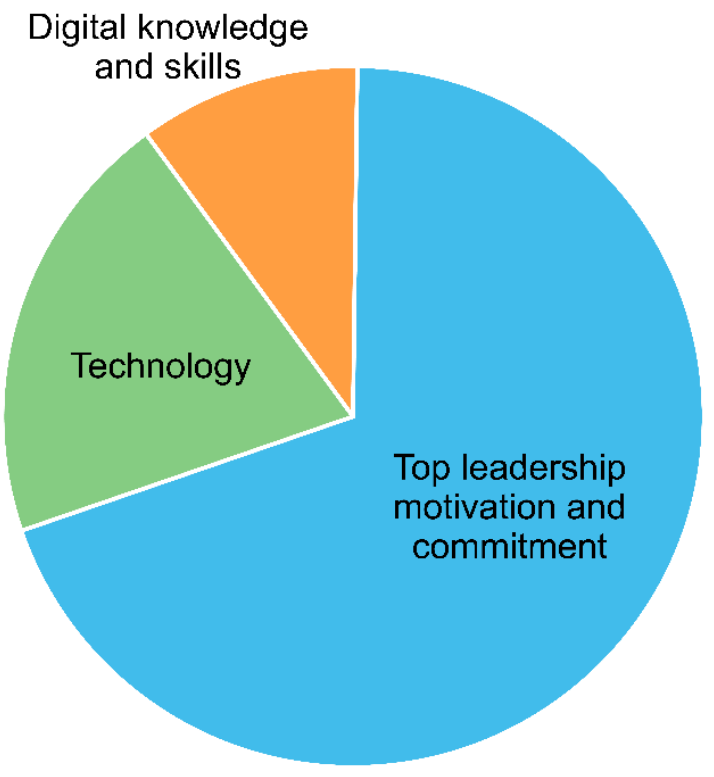

Figure 8. Key solutions associated with politics for building a super smart nation. Source: Authors' work, based on analysis of study results.

Top Leadership Motivation and Commitment

Experts R1, R2, R5, R6, and R12 express that having exemplary political leadership, understanding, motivation, and commitment is crucial. Without firm political leadership, commitment, and motivation, long-term objectives cannot be achieved. Furthermore, R12 gives Estonia's former president as an example, as he was a former tech guru and saw the opportunity for a small country to expand its horizons using digital footprint. Moreover, R3, R5, and R12 state that shared goals, vision, and mission, and involving the right stakeholders by motivating them to support building a super smart nation with agility, is fundamental in understanding the changing global circumstances. On the one hand, R1 and R5 express that long-term planning with goals is beneficial (e.g., Japan has planned for 
the next 100 years and China has a long-term strategy). On the other hand, R7 states that in addition to long-term plans, execution is essential. Most nations usually have long-term plans, but execution is always a problem. Lastly, R7 mentions a need for political evolution instead of having multiparty politics of 20 or 30 parties. It is good to have between two to five parties.

Technology

Expert R2 states that, with the right motivation from leadership, technology can play a role in increasing transparency. Furthermore, R3 expresses that big data could play an essential role in identifying exemplary leadership for governance as opposed to a group of political parties selecting their leadership. Moreover, R2 and R12 express that blockchain technology can play a significant role in increasing accountability and transparency, overcoming corruption, and keeping records safe and secure.

\section{Digital Knowledge and Skills}

Experts R5, R8, and R10 mention that education and awareness are fundamental; if leaders are not knowledgeable, making a plan for long-term goals and achieving them is difficult. Therefore, leaders must be tech-savvy and execute the plans in a knowledgeable manner. Lastly, R2, R6, and R7 state that maintaining political cooperation between countries is crucial for a nation's growth.

\subsubsection{Governance}

Another pillar for building a super smart nation is governance. As notable in Figure 9, expert analysis of this data shows that the government's developing policies, regulations, and laws, taking proactive measures, top-down or forced-to-do approach, leadership, and use of advanced technologies are considered solutions for building a super smart nation. After analyzing the data, we group all relevant solutions suggested by experts under the governance pillar.

\section{Governance}

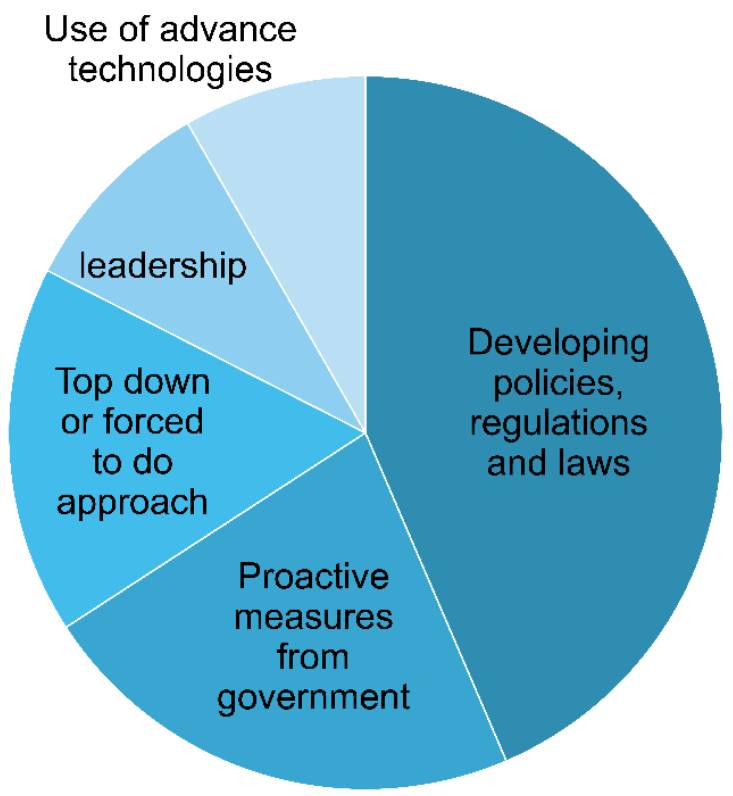

Figure 9. Key solutions associated with governance for building a super smart nation. Source: Authors' work, based on analysis of study results. 
Developing Policies, Regulations, and Laws

R5 states that developing policies, regulations, and laws is essential to building a super smart nation. R5 goes on to say that, in the future, we need to automate the execution of policies, regulations, and laws for super smart nations. Further, compliance by infrastructure like privacy by design, transparency by design, accountability by design, and everything by design are critical aspects of a super smart nation. Furthermore, R2 mentions that governments must develop a legal framework that does not kill innovation (e.g., cryptocurrency is banned in India). In addition, R7 expresses that the government must develop regulatory policies and frameworks by involving key stakeholders and provide necessary guidance and required expertise for sustainable development.

Similarly, R3 mentions a need to develop policies, regulations, and laws on data security, privacy, and the use of public data. R11 expresses that there is a need for standardization of all data types and data processing. Therefore, these regulations can help in the management of data. Moreover, R5 states that compliance with infrastructure is required to manage the quality and security of data. Further, R3 mentions the need for new regulations regarding how corporations can use public data through data protection and privacy laws. R5 further states the need to develop a regulatory framework on telecom equipment reliability. Additionally, R3 expresses the need for a regulatory framework or document that states our rights regarding digital infrastructure.

On a different note, R11 expresses the need to develop policies, regulations, and laws with regard to organizational workflows, accountability of robots, places to keep robots, certification of robots, and rules and regulations that every robot, machine, and person should follow in addition to a need to develop separate divisions for robots. Furthermore, R7 mentions that the government should develop a policy on robot use such that it helps employees and companies simultaneously. Moreover, R3 expresses the need to develop new labor laws by considering the regulations of robots. In addition, there is a need for a system that could balance technology and resources equally and establish a board of control, as currently, there are no regulations regarding malpractice or mistakes in the use of robots because there is no accountability for robots. R3 goes on to say that robots should belong to people, as in the case of computers, the persons using the computers take responsibility if something goes wrong. Similarly, advanced devices, such as robots, must be the responsibility of real humans. In contrast, R10 states the fact that Volvo, the car manufacturer, takes responsibility for mistakes in their faulty autonomous driving system as another solution.

Additionally, R7 mentions that the government must make more innovative moves toward building a super smart nation that will help develop low energy consumption devices and account for complementary industries and technologies. Some countries, such as India and China, are still dependent on coal, and others are pushing toward electric vehicles. Furthermore, R10 expresses that standardization is essential (e.g., COVID-19 vaccine certification) and there is a need to have global standards for the use of global technologies. However, it is essential to set the standard and interoperability from this point of view as well. Similarly, giving Bluetooth and USB 2.0 and 3.0 as examples, R4 states that international standards are essential, as they facilitate trade standardization. In addition, R7 expresses that there is a need for a central regulatory body irrespective of the councils of the different states. Further, cross-border trade must be a more streamlined process as in space exploration. For space exploration, most countries work together without restrictions. However, trade functions differently. For example, countries may conduct selective trading with respect to other countries' products. Therefore, it is crucial that governments establish a kind of trade body to work together.

Proactive Measures from Governments

Expert R2 expresses that governments' proactive measures can be considered as significant factors for the development of super smart nations through digitalization as in Denmark and other European countries. Furthermore, R1 mentions that following 
the steps of developed nations by identifying the gaps for the development of gigabyte speed, and then moving quickly toward achievement can be viewed as a proactive measure. Additionally, R1 goes on to say that some nations are following the lead of Canada, the United States, Australia, New Zealand, and Scandinavia. Moreover, R4 and R7 express that the government must play an active role in establishing infrastructure, supporting the use of technology, incentivizing people to use technology, encouraging people to participate and contribute to their national development for benefits and good career opportunities, and encouraging people to use specific mobile applications and schemes to purchase devices.

In addition, R5 states that reducing uncertainty from the government's side is crucial. Accordingly, R5 says that the government should play a significant role in building the vision of a super smart nation; otherwise, companies will not make investments due to uncertainty. Furthermore, R7 states that the government should create a vision by scaling up technology through scenario planning. R1 expresses that the government should act as a supporting pillar by creating an environment for good incomes, decent jobs, and creative work. Similarly, R3 mentions that smart data would help us to understand the demand system accurately and create solutions accordingly, such that funds are used wisely and for correct requirements.

\section{Top-Down or Force-to-Do Approach}

Experts mention that a top-down or force-to-do approach is another solution. R1 mentions authoritarian countries, such as China and Russia, imposing the need for and use of technology on people. Likewise, R3 references the Indian government's actions regarding the use of digital technology in 2016 during the demonetization of the currency. Similarly, R10 expresses that pandemics, such as COVID-19, are forcing people to adopt the use of technology. In addition, R8 expresses that the government should force application developers toward developing user-friendly applications. R8 and R4 go on to say that national development policies concerning having more children, as in China and developed nations changing immigration policies by encouraging a skilled workforce, are solutions to overcome the challenges of an aging population and shrinking workforce. Additionally, R2 advocates the national policies of imposing appropriate taxes based on income without loopholes. Moreover, R7 proposes that offering staggered solutions for educated people, rich people, and rural people can help to reduce social and economic disparities.

Further, R12 references Australia building a digital identity scheme through a public consultation program and creating a digital identity dashboard to highlight the importance of stakeholder involvement. Thus, the public can give their views and consent on what is acceptable. Other experts express that the government should involve people in critical decisions through awareness programs to make them feel involved and satisfied. Additionally, R7 states that people learn from other examples or use cases of other countries and talk about the best practices. Therefore, it is vital to get them involved by explaining the use cases of other countries.

\section{Leadership}

The experts further mention that leadership could be viewed as one of the solutions to overcome these challenges. R3 expresses that, for example, Microsoft and Google do not follow the traditional culture of handing over the company to their children or local people. Instead, they identify and choose exemplary leadership based on merit. Such a model can help in choosing exemplary leadership for governance as well. Additionally, R7 states that there should be strict requirements for the criteria and skills needed to become a minister, including education, technology, knowledge, and experience outside of politics.

Furthermore, R5 expresses that this problem can be overcome by creating a sense of urgency and stability with a long-term strategy for leadership. R1 mentions that it depends on the country and people's trust in the government. As in some countries, leadership and trust in the government have been challenged. Some experts express that proper motivation from the leadership and increasing the budget for sustainability are essential. R2 expresses 
that the biggest challenge for governments is to understand innovation and devise a legal framework that does not hamper innovation. Since innovation is backed by people, the government must devise mutually agreeable regulatory frameworks. However, R1 cites the Singapore government as an example, and references the fact that the government has a high level of trust in civil servants, provides them with good pay, and fires them if they fail to perform.

Use of Advanced Technologies

Expert R5 mentions that the use of semantic technologies with accountability by design, transparency by design, regulatory frameworks, and policies by design, and automating these frameworks is essential. Furthermore, R3 expresses that blockchain can help minimize public money by improving its efficiency and increasing transparency. In addition, R2 and R8 express that blockchain technology can play a significant role in automating some activities and increasing security and privacy. Moreover, R3 states that AI and the Internet of Things can help us understand human behavior in choosing appropriate people and specialists with respect to national requirements and public opinion.

\subsubsection{Economics and Business}

Another pillar for building a super smart nation is economics and business. As observable in Figure 10, the analysis of this data from experts shows that encouraging entrepreneurship, self-sustainability measures, and public and private partnerships are solutions for building a super smart nation. After analyzing the data, we group all the relevant solutions suggested by experts under the economics and business pillar.

\section{Economics and business}

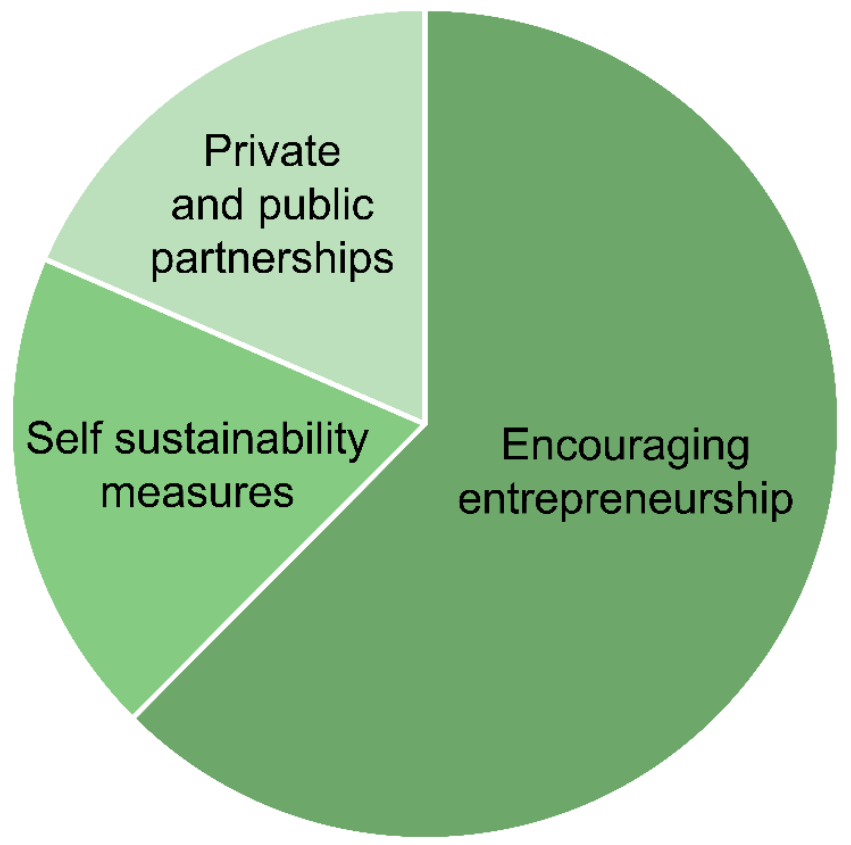

Figure 10. Key solutions associated with economics and business for building a super smart nation. Source: Authors' work, based on analysis of study results.

\section{Encouraging Entrepreneurship}

Expert R7 proposes that the government could devise a formal way to engage with startups, which will contribute to the growth of societies by incentivizing startups on the road to building a super smart nation. In other words, it is crucial to facilitate the growth of startups as opposed to selling the firms to cash in on a popular idea. Furthermore, R4 expresses that the government must develop economic policies to increase funding for micro, small, and medium enterprises; develop special economic zones to set up startup 
shops in the region; and fine-tune the banking system by encouraging entrepreneurship and taking risky steps that may be helpful for promoting entrepreneurship. Moreover, R12 cites Estonia as an excellent example in the promotion of entrepreneurship. In addition, there are initiatives in the US by many venture capitalists and government programs to minimize the barriers to entry with respect to the startup community, including providing capital to those startups that require it for building infrastructure.

Likewise, R3 has expressed that identifying talent irrespective of previous education, grades, age, gender, or color is equally important to promote entrepreneurship and innovation. This can be done by taking advantage of hackathons, which present challenges for random people and create opportunities for them with investment opportunities, such that, regardless of age and education, talent and resources from the world over can be identified to solve global problems. Similarly, R2 states that promoting entrepreneurship among students can be viewed as a possible solution. R7 mentions that his companies extend free consulting services to startups as part of corporate social responsibility to encourage entrepreneurship and innovation.

\section{Self-Sustainability Measures}

R3 mentions the significance of self-sustainability measures by local institutions for the development of super smart nations. In other words, local institutions do not have to depend on any other entities to build their power resources, and developing intelligent transport systems for a super smart nation or smart city is not only about technology, but also about enhancing lives to be more simplified and healthier. Additionally, R3 goes on to cite Switzerland, which developed technology for itself and equally for the global requirement, as an example. Thus, the concept of a super smart nation includes helping increase the quality of life of other people as well. Furthermore, R6 expresses that the government can provide guidelines on areas that may receive governmental help initially, but must later be supported by companies.

\section{Private-Public Partnerships}

R5 states that public-private partnerships are a solution to overcome this challenge. In addition, R5 goes on to say that the government must create a collaborative ecosystem for companies, businesses, and governments regarding incentives and subsidies by encouraging and inviting companies to participate in super smart nation development. Furthermore, R11 expresses that companies would play a significant role, as governments in some nations do not have the required resources. Here, companies must fund the resources, push for research, encourage startups by reaching out to people, and build a digital society.

\subsubsection{Sustainability}

Sustainability is another pillar for building a super smart nation. As observable in Figure 11, expert analysis of this data shows that the development of sustainable energy sources, international cooperation, and trade agreements are relevant solutions. After analyzing the data, we group all relevant solutions suggested by experts under the sustainability pillar.

\section{Development of Sustainable Energy Sources}

Experts R5 and R11 mention that sustainable energy sources can be considered a solution, as we have plenty of natural sources, and bioeconomy, such as solar energy, a promising and sustainable solution. Similarly, recycling is a good solution as opposed to throwing away old devices. Likewise, the present oil prices are relatively cheaper, but they are damaging our planet. R2 expresses that Denmark receives $50-60 \%$ of its total energy from wind power. Developing countries like India are moving toward such energy sources as well. R12 references the Australian government pushing for solar panels on the roofs of all houses in Australia by providing subsidies. However, R8 expresses that the lack of 
natural resources is not a problem, and this can be overcome with international cooperation and collaborations (e.g., Singapore supporting other nations with technology).

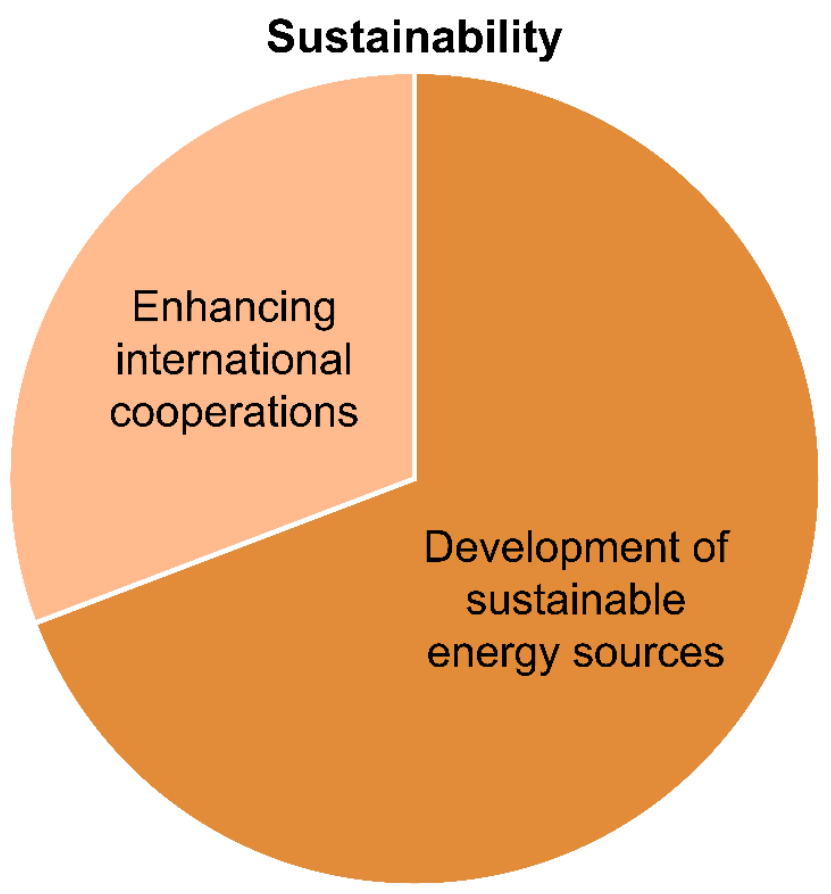

Figure 11. Key solutions associated with sustainability for building a super smart nation. Source: Authors' work, based on analysis of study results.

International Cooperation and Trade Agreements

R7 states that international cooperation and trade agreements are essential to overcome some of China's challenges. China controls most of the rarer minerals used to produce mobile phones. If China stops producing or stops allowing other companies or countries to access these minerals, it will pose a severe challenge. China can potentially monopolize some resources. In addition, R12 mentions that internet and cybersecurity treaties are crucial for national security within countries.

\section{Discussion and Conclusions}

Figure 12 illustrates the framework for building a super smart nation based on a literature review of stakeholders, characteristics, challenges, and solutions (see Background Information and Results sections), using a scenario planning technique. The overall objective of building a super smart nation is to facilitate living, conducting business, offering public services, enhancing international cooperation for socio-economic development, and overcoming future social problems. The theories that have been developed to create a people-centric and super-smart society and smart nations can be incorporated into building a super-smart nation. 


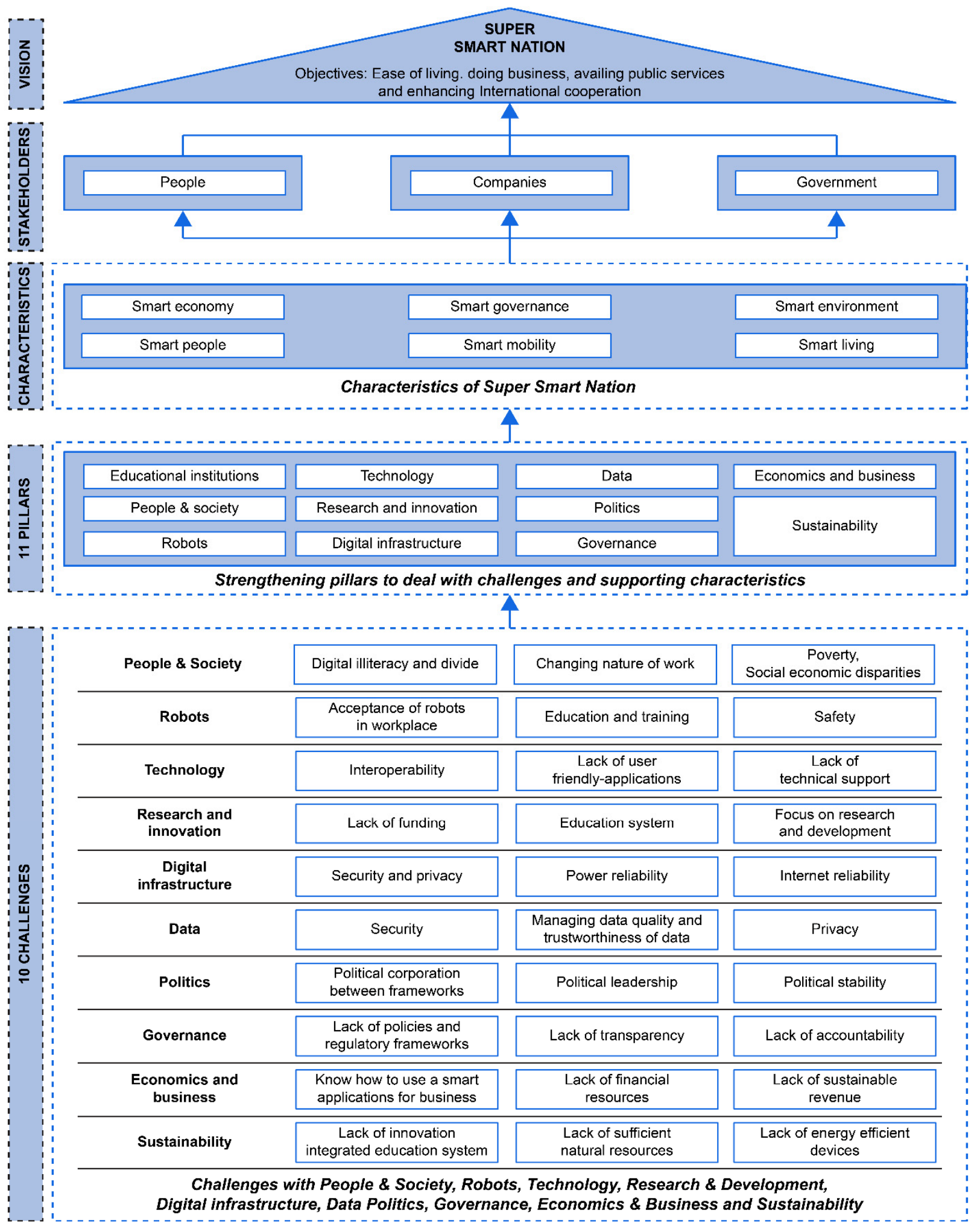

Figure 12. The framework of a super smart nation. Source: Authors' work, based on analysis of study results.

Using the results from the Delphi methodology, as shown in Figure 12, a new framework is built to generate value for all key stakeholders, namely, the government, companies, and people. The framework has six characteristics-smart economy, smart people, smart governance, smart mobility, smart environment, and smart living; and 11 categories of 
pillars-people and society, educational institutions, robots, technology, innovation and entrepreneurship, digital infrastructure, data, politics, governance, economics and business, and sustainability. These stakeholders, characteristics, and pillars help in creating a super smart nation and overcoming the corresponding challenges. These pillars are developed based on challenges (see Results sections) and were identified and analyzed through experts' discussions and interviews. This study helps identify 10 categories of challenges and 11 pillars of solutions, as opposed to extant research, which provides only six categories of challenges in smart cities and digital nations. The characteristics of a super smart nation continuously interact with each other using cyber-physical systems and future technologies, such as ambience intelligence. Continuous interactions between humans and machines provide opportunities for the development of super smart nations.

According to earlier research by Penmetsa and Bruque [39], the concept of digital nations is developed by adopting the theories that could stem from digital government, digital business, and digital societies. Moreover, digital government theories can facilitate the transformation of digital nations by broadly outlining plans for the relationship between governments and citizens (G2C), between the government and businesses and industrial departments (G2B), and among different government units (G2G) [40-42]. Furthermore, research on digital nations has three main elements: digital government, digital business, and digital society; and six categories of challenges and pillars-people, technology, institutions, policy, economics, and sustainability. This study was focused on building a digital nation framework to promote ease of living, conduct business, offer citizens public services, and identify the characteristics and mainly challenges at a national level.

Similarly, early research on smart nations focuses on how urban and rural citizens, government, and businesses live in a smart society, to improve public services, mobility, trade, business, and high efficiency living standards. The overall objective of building a smart nation is for ease of living and doing business and to offer better public services and resolving endemic urban problems, such as ageing, energy crises, pollution, safety, and crime through the use of advanced technologies, such as artificial intelligence, big data, 5G, and other networks that connect humans and machines. The building blocks of a smart nation are based on digital concepts, such as digital nations, and smart cities [14,43-45] concept is developed to allow citizens to access better health services, education, and technology, as well as equal work opportunities with ease, and enable sustainable development at sub-regional and national levels. It involves three stakeholders: the government, economy, and society, and has six characteristics: smart economy, smart people, smart governance, smart mobility, smart environment, and smart living of smart cities. Moreover, there are seven pillars: people and society, technology and innovation, digital infrastructure, politics, governance, economics and business, and sustainability to accelerate digitalization and develop smart societies.

The study of building a super smart nation also illustrates some important solutions to overcome potential challenges that have not been addressed by prior research on digital nation, smart nations, and smart cities.

The creation of super smart nations is initiated by the people. To create a smarter society, awareness programs (using celebrities and other society influencers) need to be developed. Furthermore, it would be helpful to educate citizens about successful use cases in Japan and other comparable countries; to identify the segments of people who are digitally illiterate, to visit their homes and motivate them to use technology; to design devices that are easy for the elderly to see and operate; and to provide free devices to needy people. Moreover, it is also very important to instill more confidence among workers that they will be trained and educated about operating robots at work. Additionally, it creates the perception among humans that robots will not replace them.

Robotics is crucial for nations dealing with an aging population and a declining workforce. The use of cases of successful technology adoption in countries to overcome these challenges is a helpful starting point (ideal to start using robots at home before integrating them into businesses; Japan is a great example for learning more about robots and 
cultural compatibility when using technology). Likewise, the use of advanced technologies, such as robotics and automation (such as the Amazon Go store in the United States, which is run solely by robots, just the people who manage it) is seen as a way to create a super-smart nation.

Likewise, technologies are considered crucial to super-smart nations. Technology (the development of technologies through public-private partnerships; open-source collaboration) can be a useful tool for collaboration and attaining common goals. It is also crucial to develop an interoperable infrastructure that is compatible with multiple advanced technologies, such as blockchain, artificial intelligence, and 5G. Moreover, creating a single platform for interoperability across numerous use cases is beneficial.

A super smart nation also relies on research and innovation. According to the results, a global standard for education systems can be developed based on an innovation-based education system like global standards for mobile phones, the Internet, and cars. Further, the development of an innovation ecosystem (involving governments, companies, researchers, and citizens) and increasing the budget for research and development (increase funding for the adoption of technology; the need for research and development on Internet bandwidth regarding future technologies, such as 6G; research on sustainable energy and sustainable development initiatives). Additionally, forming public and private partnerships (such as creating a collaborative ecosystem by encouraging and inviting companies, encouraging startups) and developing infrastructure (developing interoperable infrastructure) could also be beneficial.

Digital infrastructure is also a prerequisite for a super-smart nation. Among the solutions to overcome challenges are ensuring cybersecurity and privacy using blockchain technology; ensuring accessibility to digital infrastructure (making access to the Internet a fundamental right; developing Internet satellite infrastructure such as star links); and implementing infrastructure regulatory frameworks and initiating policies similar to Africa Partnership Model, which allows foreign direct investment approval on a single-window basis.

Super-smart nations rely on data as well. To overcome the challenges, experts have advised that blockchain technology, which can protect sensitive data and is compliant by design with mechanisms for self-sovereign identities, and semantic technologies, which can deliver proactive solutions, can contribute to the development of a smart nation.

Super smart nations begin with an unwavering commitment from the nation's top leadership and political pillar. Some of these include top leadership commitment (e.g., Estonia's former president was a technologist); developing long-term goals (e.g., Japan has planned for the next 100 years); and developing a vision and mission (by involving right stakeholders such as people, companies, and government).

In addition, a super-smart nation must have effective governance. The findings of the study indicate that these challenges can be overcome through proactive steps from the government (such as identifying the gaps for the development of gigabyte speed, then moving quickly toward achievement; government playing an active role in establishing infrastructure, and encouraging people to participate in and contribute to national development) and creating awareness programs (on the benefits of robotics and automation). Additional issues include the development of policies, legal frameworks, and laws (automating the execution of policies, regulations, and laws through compliance; developing infrastructure for privacy, transparency, and accountability by design; a legal framework that does not dampen innovation; and developing policies, regulations, and laws on accountability of robots) can help strengthen the governance pillar. Further, educational institutions could also be an instrumental support for governance. This can be done by transforming the education system (transforming the education system as in Finland and South Korea, and developing long-term strategies and policies as in Estonia, by teaching coding in schools from the age of 5 years; developing global uniform education standards).

Another pillar is economics and business. Among the solutions for overcoming these challenges is encouraging entrepreneurship (incentivizing startups on the road to build a super smart nation and identifying talent irrespective of previous education, grade, age, 
gender, or color). Further, implementing self-sustainability measures for economics and business (build own power resource and guidelines for initial governmental assistance); focusing on sustainable energy sources (bioeconomy, solar energy, and wind power); and enhancing international cooperation and collaboration.

Sustainable development of super smart nations relies on sustainability as well. Among the solutions to these challenges can be found the development of sustainable energy sources (bioeconomy, including solar energy, is promising; recycling old devices as an alternative to throwing them away), international cooperation, and free trade agreements.

The characteristics of a super smart nation continuously interact with each other using cyber-physical systems and future technologies, such as ambience intelligence. Continuous interactions between humans and machines provide opportunities for the development of super smart nations.

Furthermore, the study of super smart nations follows a "whole-nation" approach by involving the three key stakeholders-governments, companies, and citizens-along with six characteristics of a super smart nation for ease of living; doing business; offering public services; and enhancing international cooperation between developed, emerging, and developing nations to overcome socioeconomic development and social problems. The primary objective of a super smart nation is to overcome the challenges stemming from the increase in aging populations, decreasing birth rates, shrinking workforces, increasing costs for social security services and healthcare, pandemics, natural disasters, and trade wars. Thus, the framework developed in this study serves as a global roadmap for countries regarding fostering the use of super smart concepts and advanced technologies such as 6G telecommunication networks; advanced 3D printing; ambient intelligence; AI; battery technologies; big data; blockchain; cloud computing; cyber-physical systems; cyborg enhancement technologies; drones; the Internet of Things; machine learning; smart mobile phones; robots; and sensors to achieve the United Nations' SDGs at national, regional, and global levels.

A super smart nation could be built through international cooperation among developed and developing countries. By integrating cyberspace, physical space, and humanity, this study can have significant implications at the sub-regional, national, continental, and global levels for building nations with the ability to overcome and solve social problems. We discuss a variety of stakeholders, characteristics, pillars, and challenges as well as factors that may determine whether a super smart nation is successful. As digitalization activities are being rapidly carried out, especially in developed markets where aging populations, shrinking workforces, and societal problems are causing concern, this framework may be of interest to government officials and corporate executives. Further, it is useful for governments, along with scholars, since interest in smart societies has grown exponentially since the COVID-19 crisis.

We expect that super smart nation governments will help to reshape businesses and societies at sub-regional, national, continental, and global levels. In turn, companies can work closely with governments to support public services, while governments can act as facilitators that tie the three stakeholders together to achieve the UN SDGs.

We established a set of stakeholders, characteristics, pillars, and challenges that could help facilitate digital transformation. This super smart nation framework may interest public administrations and researchers involved in digitalization who study the critical challenges within the 10 categories listed above, along with identified solutions, and thus pursue the building of a super smart nation for developed, emerging, and developing economies.

Nevertheless, this study has some limitations. First, our work is mainly derived from interviews with a small group of 12 subject matter experts. The structure of a super smart nation could have been further reviewed through additional interviews with experts from governments, companies, and citizens, instead of experts with research experience on this topic and through the Delphi methodology. Future studies can examine exploratory research using national case studies at the individual level for scenario planning. Furthermore, future studies can select research studies with common characteristics at the national, 
continental, and global levels. Our research will continue to improve our findings through expert interviews and national scenario planning by involving the three stakeholders to enable the development of a super smart nation.

Supplementary Materials: The following supporting information can be downloaded at https:/ / www.mdpi.com/article/10.3390/su14052757/s1. Questionnaire.

Author Contributions: Conceptualization, M.K.P.; methodology, M.K.P.; formal analysis, M.K.P.; investigation, M.K.P.; data curation, M.K.P.; writing—original draft preparation, M.K.P.; writingreview and editing, M.K.P.; supervision, M.K.P. and S.J.B.C.; project administration, M.K.P. All authors have read and agreed to the published version of the manuscript.

Funding: This research received no external funding.

Institutional Review Board Statement: Not applicable.

Informed Consent Statement: Not applicable.

Data Availability Statement: The data presented in this study are available on request from the corresponding author. The data are not publicly available to ensure that data shared are in accordance with consent provided by participants on the use of confidential data.

Acknowledgments: We would like to thank the experts for their participation in and contribution to this study.

Conflicts of Interest: The authors declare no conflict of interest.

\section{Appendix A}

Table A1. Ten Categories of Key Challenges Associated with Building a Super smart Nation.

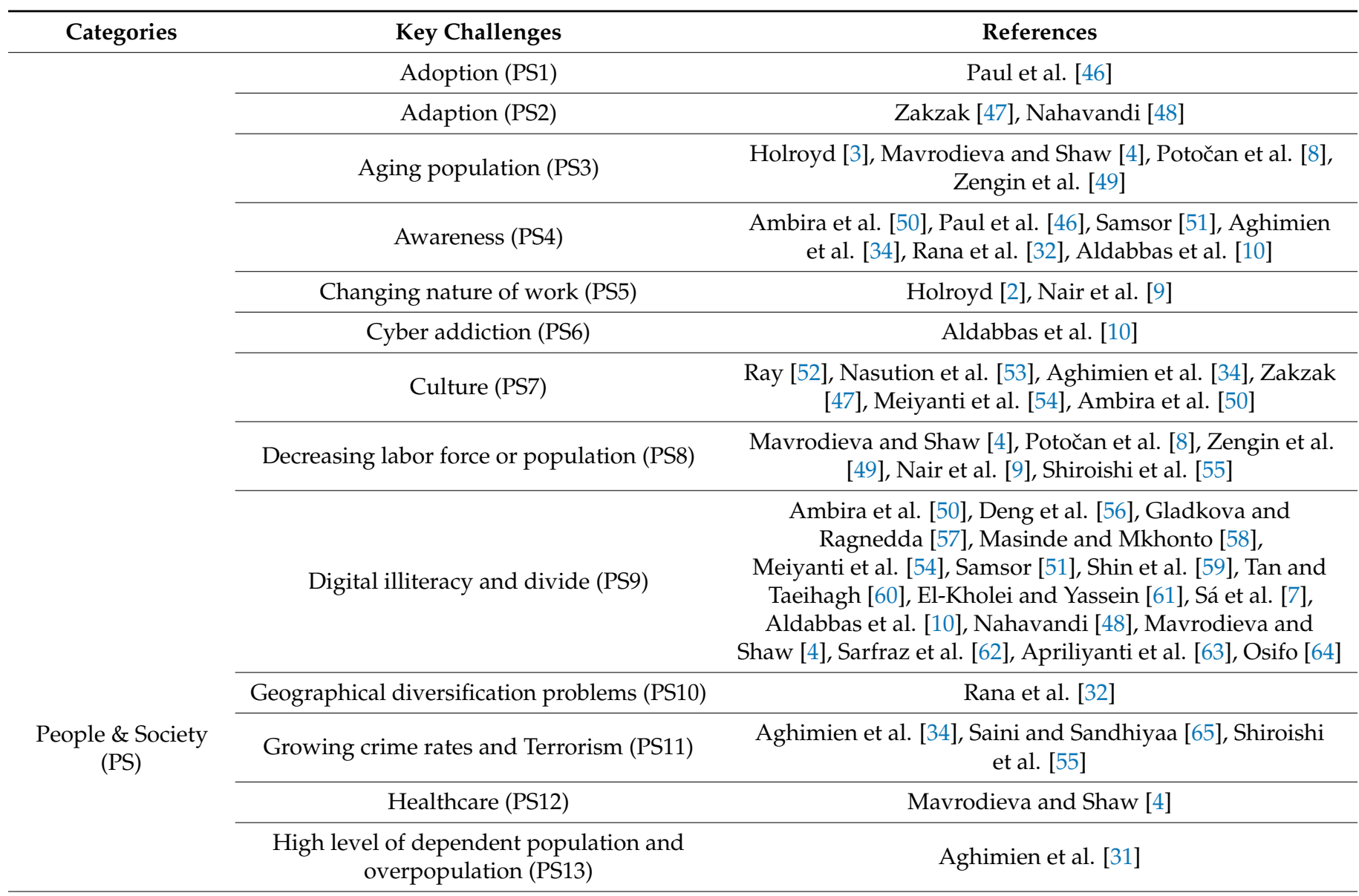


Table A1. Cont.

\begin{tabular}{|c|c|c|}
\hline Categories & Key Challenges & References \\
\hline & High rate of unemployment (PS14) & $\begin{array}{l}\text { Aghimien et al. [34], Aghimien et al. [31], Zengin et al. [49], } \\
\text { Aldabbas et al. [10] }\end{array}$ \\
\hline & $\begin{array}{l}\text { Inclusion of communities and participation } \\
\text { (PS15) }\end{array}$ & Mavrodieva and Shaw [4], Potočan et al. [8] \\
\hline & Internet gaming disorder (PS16) & Aldabbas et al. [10] \\
\hline & Issues of ethics and different values (PS17) & Mavrodieva and Shaw [4] \\
\hline & Increase in population rate (PS18) & Aghimien et al. [34], Rana et al. [32] \\
\hline & Lack of citizen participation (PS19) & $\begin{array}{c}\text { Aghimien et al. [34], Rana et al. [32], Tan and Taeihagh [60], } \\
\text { El-Kholei and Yassein [61] }\end{array}$ \\
\hline & Motivation for compliance (PS20) & Aldabbas et al. [11] \\
\hline & Poverty (PS21) & Aghimien et al. [34], Aghimien et al. [31], Zengin et al. [49] \\
\hline & Skilled technological support (PS22) & Sarfraz et al. [62] \\
\hline & Social and economic disparities (PS23) & $\begin{array}{l}\text { Mavrodieva and Shaw [4], Ray [52], Meiyanti et al. [54], } \\
\text { Zakzak [47], Potočan et al. [8], Aldabbas et al. [10] }\end{array}$ \\
\hline & Social acceptance (PS24) & $\begin{array}{c}\text { Shiroishi et al. [55], Aldabbas et al. [10], Tan and } \\
\text { Taeihagh [60] }\end{array}$ \\
\hline & $\begin{array}{l}\text { Women empowerment and gender bias } \\
\text { (PS25) }\end{array}$ & Saini and Sandhiyaa [65], Aldabbas et al. [10] \\
\hline \multirow{5}{*}{ Robots } & Humans competing with robots (R1) & Demir et al. [66] \\
\hline & Learning to work with robots (R2) & Demir et al. [66] \\
\hline & $\begin{array}{l}\text { Personal preference toward working with } \\
\text { robots (R3) }\end{array}$ & Demir et al. [66] \\
\hline & $\begin{array}{l}\text { Social and psychological issues resulting } \\
\text { from human-robot co-working (R4) }\end{array}$ & Demir et al. [66] \\
\hline & $\begin{array}{l}\text { Technology vs. Humans: Who is in the } \\
\text { driver's seat (R5) }\end{array}$ & Aldabbas et al. [10] \\
\hline \multirow{12}{*}{ Technology (T) } & Access to latest technologies (T1) & $\begin{array}{l}\text { Oni et al. [67], Rana et al. [32], Aghimien et al. [31], } \\
\text { Shiroishi et al. [55], Holroyd [3], Nair et al. [9] }\end{array}$ \\
\hline & Application development (T2) & Nasution et al. [53], Jo et al. [68] \\
\hline & Big data (T3) & Silva et al. [38], Farid et al. [69] \\
\hline & Data availability and heterogeneousness (T4) & $\begin{array}{c}\text { Zengin et al. [49], Aldabbas et al. [10], Rana et al. [32], Tan } \\
\text { and Taeihagh [60], El-Kholei and Yassein [61] }\end{array}$ \\
\hline & $\begin{array}{l}\text { Hardware environment compatibility and } \\
\text { heterogeneity (T5) }\end{array}$ & Silva et al. [38], Aldabbas et al. [10], Meiyanti et al. [54] \\
\hline & Information technology standards (T6) & Ambira et al. [50], Shin et al. [59] \\
\hline & $\begin{array}{l}\text { Information security management } \\
\text { professionals (T7) }\end{array}$ & Tonggiroh [41] \\
\hline & Lack of technological skills (T8) & Meiyanti et al. [54] \\
\hline & Lack of technical support equipment (T9) & Zengin et al. [49] \\
\hline & Poor utilization of digital technologies (T10) & Aghimien et al. [34] \\
\hline & Records mobility (T11) & Meiyanti et al. [54] \\
\hline & Data and System integration (T12) & Meiyanti et al. [54], Jo et al. [68] \\
\hline
\end{tabular}


Table A1. Cont.

\begin{tabular}{|c|c|c|}
\hline Categories & Key Challenges & References \\
\hline \multirow{5}{*}{$\begin{array}{l}\text { Research and } \\
\text { innovation (RI) }\end{array}$} & $\begin{array}{l}\text { Focus on research and development on } \\
\text { technologies (RI1) }\end{array}$ & Mavrodieva and Shaw [5] \\
\hline & Increased cost of development (RI2) & Mavrodieva and Shaw [5] \\
\hline & Innovation ecosystem (RI3) & Osifo [64], Ray [50], Shin et al. [59] \\
\hline & $\begin{array}{l}\text { Successful investment in a disruptive } \\
\text { technology (RI4) }\end{array}$ & Holroyd [3] \\
\hline & Lack of funding (RI5) & Sarfraz et al. [62] \\
\hline \multirow{12}{*}{$\begin{array}{l}\text { Digital } \\
\text { infrastructure (DI) }\end{array}$} & Availability (DI1) & Ambira et al. [50], Shin et al. [59] \\
\hline & Access to computer and technology (DI2) & $\begin{array}{c}\text { Chia [5], Masinde and Mkhonto [58], Paul et al. [46], } \\
\text { Ray [52], Rana et al. [32], Aghimien et al. [31], Tan and } \\
\text { Taeihagh [60], El-Kholei and Yassein [61], } \\
\text { Nasution et al. [53], Ambira et al. [50], } \\
\text { Apriliyanti et al. [63], Deng et al. [56], Samsor [51], } \\
\text { Meiyanti et al. [54] }\end{array}$ \\
\hline & $\begin{array}{l}\text { Common information system (IS) and } \\
\text { interactive public services (DI3) }\end{array}$ & Aghimien et al. [34], Shin et al. [59] \\
\hline & Different infrastructure systems (DI4) & Farid et al. [69], Zengin et al. [49] \\
\hline & Digital social movements (DI5) & Aldabbas et al. [10] \\
\hline & $\begin{array}{l}\text { ICT infrastructure support and } \\
\text { coordination (DI6) }\end{array}$ & $\begin{array}{c}\text { Ambira et al. [50], Apriliyanti et al. [63], Deng et al. [56], } \\
\text { Samsor [51], Farid et al. [69] }\end{array}$ \\
\hline & Lack of qualifications (DI8) & Meiyanti et al. [54] \\
\hline & $\begin{array}{l}\text { Network, telecommunication infrastructure, } \\
\text { and internet connectivity (DI9) }\end{array}$ & $\begin{array}{l}\text { Ambira et al. [50], Gladkova and Ragnedda [57], Masinde } \\
\text { and Mkhonto [58], Paul et al. [46], Shin et al. [59], } \\
\text { Tonggiroh [41], Meiyanti et al. [54], Potočan et al. [8], } \\
\text { Zengin et al. [49], Aghimien et al. [34], Silva et al. [38], Farid } \\
\text { et al. [69], Aghimien et al. [31], Sarfraz et al. [62] }\end{array}$ \\
\hline & Risks to digital rights (DI10) & Aldabbas et al. [10] \\
\hline & Sensing technology (DI11) & Farid et al. [69] \\
\hline & System failures issues (DI12) & Rana et al. [32], Silva et al. [38], Aghimien et al. [34] \\
\hline & Trust in e-voting (DI3) & Aldabbas et al. [10] \\
\hline \multirow{7}{*}{ Data (D) } & Data availability and heterogeneousness (D1) & $\begin{array}{l}\text { Zengin et al. [49], Aldabbas et al. [10], Rana et al. [32], Tan } \\
\text { and Taeihagh [60], El-Kholei and Yassein [61] }\end{array}$ \\
\hline & $\begin{array}{c}\text { Information and cyber security, privacy, } \\
\text { trust (D2) }\end{array}$ & $\begin{array}{l}\text { Rana et al. [32], Jo et al. [68], Chia [5], Oni et al. [67], } \\
\text { Osifo [64], Paul et al. [46], Samsor [51], Shin et al. [59], } \\
\text { Sulistya et al. [70], Aghimien et al. [34], Aghimien et al. [31], } \\
\text { Nasution et al. [53], Mavrodieva and Shaw [4], Aldabbas } \\
\text { et al. [10], Nair et al. [9], Osifo [64], Paul et al. [46] }\end{array}$ \\
\hline & $\begin{array}{l}\text { Veracity (managing the data quality, } \\
\text { uncertainty, and trustworthiness of data) (D3) }\end{array}$ & Chauhan et al. [71] \\
\hline & $\begin{array}{l}\text { Value (data is worthless until it is converted } \\
\text { into value) (D4) }\end{array}$ & Chauhan et al. [71] \\
\hline & $\begin{array}{l}\text { Velocity (speed at which data must be } \\
\text { analyzed) (D5) }\end{array}$ & Chauhan et al. [71] \\
\hline & $\begin{array}{l}\text { Human dynamics (humans' role in data } \\
\text { collection, data analysis, and decision } \\
\text { making) (D6) }\end{array}$ & Chauhan et al. [71] \\
\hline & Volume (huge amount of data) (D7) & Chauhan et al. [71] \\
\hline
\end{tabular}


Table A1. Cont.

\begin{tabular}{|c|c|c|}
\hline Categories & Key Challenges & References \\
\hline \multirow{14}{*}{ Politics (P) } & $\begin{array}{l}\text { Coordination, collaboration, and consultation } \\
\qquad(\mathrm{P} 1)\end{array}$ & $\begin{array}{l}\text { Aghimien et al. [34], Rana et al. [32], Khan et al. [72], } \\
\text { Meiyanti et al. [54], Osifo [64], Samsor [51], Shin et al. [59] }\end{array}$ \\
\hline & Bribery and corruption (P2) & Ambira et al. [50], Sulistya et al. [70] \\
\hline & Common goals, vision, and mission(P3) & Rana et al. [32], Apriliyanti et al. [62] \\
\hline & Feedback system (P4) & Apriliyanti et al. [63] \\
\hline & $\begin{array}{l}\text { Fragmented authority and decision-making } \\
\text { power(P5) }\end{array}$ & Tan and Taeihagh [60], Shin et al. [59], Apriliyanti et al. [63], \\
\hline & Government support (P6) & Tonggiroh [41], Zengin et al. [49] \\
\hline & ICT implementation (P7) & Ambira et al. [50], Apriliyanti et al. [63] \\
\hline & $\begin{array}{l}\text { Lack of funding, investment, and resource } \\
\text { availability (P8) }\end{array}$ & $\begin{array}{c}\text { Tan and Taeihagh [60], Ambira et al. [50], Masinde and } \\
\text { Mkhonto [58], Osifo [64], Samsor [51], Shin et al. [59], Deng } \\
\text { et al. [56], Tonggiroh [41] }\end{array}$ \\
\hline & $\begin{array}{l}\text { Lack of public-private partnership } \\
\text { participation (P9) }\end{array}$ & Aghimien et al. [34], Rana et al. [32], Khan et al. [72] \\
\hline & Motivation (P10) & Apriliyanti et al. [63] \\
\hline & $\begin{array}{l}\text { Political stability, willingness, and leadership } \\
\text { (P11) }\end{array}$ & $\begin{array}{l}\text { Aghimien et al. [34], Rana et al. [32], El-Kholei and Yassein } \\
\text { [61], Ambira et al. [50], Apriliyanti et al. [63], Aghimien } \\
\text { et al. [34], Meiyanti et al. [54], Samsor [51], Tonggiroh [41], }\end{array}$ \\
\hline & $\begin{array}{l}\text { Poor governance/lack of trust government } \\
\qquad(\mathrm{P} 12)\end{array}$ & $\begin{array}{l}\text { Aghimien et al. [34], Rana et al. [32], Saini and Sandhiyaa } \\
\text { [65], El-Kholei and Yassein [61], Deng et al. [56] }\end{array}$ \\
\hline & Transparency (P13) & $\begin{array}{l}\text { Apriliyanti et al. [63], Meiyanti et al. [54], Shin et al. [59], } \\
\text { Sulistya et al. [70], Nahavandi, [48] }\end{array}$ \\
\hline & Turnover of workforce (P14) & Meiyanti et al. [54] \\
\hline \multirow{11}{*}{ Governance (G) } & Accountability (G1) & $\begin{array}{l}\text { Apriliyanti et al. [63], Sarfraz et al. [62], Mavrodieva and } \\
\text { Shaw [4] }\end{array}$ \\
\hline & Civil and criminal justice (G2) & Farid et al. [69] \\
\hline & $\begin{array}{l}\text { Confusing and ill-adapted tax regulations } \\
\qquad \text { (G3) }\end{array}$ & Saini and Sandhiyaa [65] \\
\hline & $\begin{array}{l}\text { Changing role of human resources } \\
\text { departments }(\mathrm{G} 4)\end{array}$ & Demir et al. [66] \\
\hline & Ethical issues and practices (G5) & $\begin{array}{l}\text { Farid et al. [69], Nahavandi [48], Aldabbas et al. [10], Demir } \\
\text { et al. [66] }\end{array}$ \\
\hline & Governmental surveillance(G6) & Aldabbas et al. [10] \\
\hline & Issues of openness of data (G7) & Rana et al. [32] \\
\hline & $\begin{array}{c}\text { Lack of regulatory frameworks, policies, and } \\
\text { directions (G8) }\end{array}$ & $\begin{array}{c}\text { Rana et al. [32], Aghimien et al. [34], Tan and Taeihagh [60], } \\
\text { Saini and Sandhiyaa [65], Meiyanti et al. [54], Chia [5], Nair } \\
\text { et al. [9], Demir et al. [66], Mavrodieva and Shaw [4], } \\
\text { Shiroishi et al. [55], Aldabbas et al. [10], Nahavandi [48] }\end{array}$ \\
\hline & Lack of transparency (G9) & $\begin{array}{c}\text { Rana et al. [32], Apriliyanti et al. [63], Meiyanti et al. [54], } \\
\text { Shin et al. [59], Sulistya et al. [70], Nahavandi [48], } \\
\text { Aldabbas et al. [10] }\end{array}$ \\
\hline & Ministries and agencies (G10) & Shiroishi et al. [56] \\
\hline & Standardization (G11) & $\begin{array}{c}\text { Aghimien et al. [34], Rana et al. [32], Shin et al. [59], } \\
\text { Nahavandi [48] }\end{array}$ \\
\hline
\end{tabular}


Table A1. Cont.

\begin{tabular}{|c|c|c|}
\hline Categories & Key Challenges & References \\
\hline \multirow{11}{*}{$\begin{array}{l}\text { Economics and } \\
\text { Business (EB) }\end{array}$} & Absence of foreign investors (EB1) & Aghimien et al. [34] \\
\hline & $\begin{array}{l}\text { Budget for operational and maintenance } \\
\qquad \text { costs (EB2) }\end{array}$ & Kwak and Lee [73], Silva et al. [38], Rana et al. [32] \\
\hline & $\begin{array}{l}\text { Growing economic disparity and volatility } \\
\text { (EB3) }\end{array}$ & $\begin{array}{c}\text { Shiroishi et al. [54], Rana et al. [32], Aghimien et al. [34], } \\
\text { El-Kholei and Yassein [61], Aghimien et al. [31], Saini and } \\
\text { Sandhiyaa [65] }\end{array}$ \\
\hline & $\begin{array}{l}\text { High cost of IT training and skills } \\
\text { development (EB4) }\end{array}$ & Aghimien et al. [34], Rana et al. [32], Aghimien et al. [31] \\
\hline & $\begin{array}{l}\text { High IT infrastructure and intelligence deficit } \\
\text { (EB5) }\end{array}$ & Rana et al. [32] \\
\hline & Increasing cost for social security (EB6) & Mavrodieva and Shaw [4] \\
\hline & Lack of competitiveness (EB7) & Rana et al. [32], Aghimien et al. [32] \\
\hline & Loss of jobs due to robots (EB8) & Aldabbas et al. [10] \\
\hline & Lack of sustainable revenue (EB9) & Kwak and Lee [73] \\
\hline & Performance (EB10) & Silva et al. [38] \\
\hline & $\begin{array}{l}\text { Weak financial resources and lack of funding } \\
\text { (EB11) }\end{array}$ & Kwak and Lee [73], Nasution et al. [53], Sarfraz et al. [62] \\
\hline \multirow{13}{*}{ Sustainability } & $\begin{array}{l}\text { Air pollution, carbon emissions, and } \\
\text { environmental degradation(S1) }\end{array}$ & Rana et al. [32], Zengin et al. [49], Holroyd [3] \\
\hline & Degradation of resources (S2) & Rana et al. [32], Shiroishi et al. [55] \\
\hline & $\begin{array}{l}\text { Diminishing food security due to climate } \\
\text { change (S3) }\end{array}$ & Mavrodieva and Shaw [4] \\
\hline & Global warming and climate change(S4) & Shiroishi et al. [55], Mavrodieva and Shaw [4] \\
\hline & High rate of urbanization (S5) & Aghimien et al. [34] \\
\hline & Increasing demand for energy(S6) & Mavrodieva and Shaw [4] \\
\hline & Lack of sustainability consideration (S7) & $\begin{array}{c}\text { Aghimien et al. [34], Rana et al. [32], Tan and Taeihagh [60], } \\
\text { Silva et al. [38] }\end{array}$ \\
\hline & $\begin{array}{l}\text { Natural disasters (e.g., earthquakes, } \\
\text { tsunamis, storms) (S8) }\end{array}$ & Holroyd [3], Mavrodieva and Shaw [4], Zengin et al. [49] \\
\hline & Poor education system (S9) & Aghimien et al. [31] \\
\hline & Poor planning of cities (S10) & Aghimien et al. [34] \\
\hline & Poor waste management (S11) & $\begin{array}{l}\text { Aghimien et al. [34], Silva et al. [38], Saini and } \\
\text { Sandhiyaa [65] }\end{array}$ \\
\hline & Power supply and energy shortages (S12) & Aghimien et al. [31], Saini and Sandhiyaa [65], Holroyd [3] \\
\hline & Traffic congestions in cities (S13) & Aghimien et al. [34] \\
\hline
\end{tabular}


Table A2. Demographic Data of Respondents (Experts).

\begin{tabular}{|c|c|c|c|c|}
\hline Respondents & Country & Expertise Area & Work Profile & $\begin{array}{c}\text { Years of Work Experience } \\
\text { (Classification) }\end{array}$ \\
\hline $\mathrm{R} 1$ & Canada & Super smart society & Academia & Greater than 20 years \\
\hline $\mathrm{R} 2$ & Denmark & $\begin{array}{l}\text { Digitalization, blockchain, big data } \\
\text { analytics, machine learning }\end{array}$ & Academia and Industry & Greater than 20 years \\
\hline R3 & India & Futurist and digital transformation & Industry & 16 to 20 years \\
\hline $\mathrm{R} 4$ & India & $\begin{array}{l}\text { Futurist, digitalization and big data } \\
\text { analytics }\end{array}$ & Industry & 16 to 20 years \\
\hline R5 & Netherlands & $\begin{array}{l}\text { Digital nation, Digital government, } \\
\text { ICT and governance }\end{array}$ & Academia & Greater than 20 years \\
\hline R6 & Singapore & Smart nations & Academia & Greater than 20 years \\
\hline R7 & Singapore & Digital transformation & Industry & 16 to 20 years \\
\hline $\mathrm{R} 8$ & South Korea & $\begin{array}{c}\text { Blockchain, cybersecurity, } \\
\text { AI, Internet of things, smart cities, } \\
\text { industry } 4.0\end{array}$ & Academia & 5 to 10 years \\
\hline $\mathrm{R} 9$ & South Korea & Futurist & Industry & Greater than 20 years \\
\hline $\mathrm{R} 10$ & Switzerland & $\begin{array}{l}\text { Artificial Intelligence, machine } \\
\text { learning and blockchain }\end{array}$ & Academia & 5 to 10 years \\
\hline R11 & Turkey & $\begin{array}{l}\text { Human robot co-working and } \\
\text { industry } 5.0\end{array}$ & Industry & Greater than 20 years \\
\hline $\mathrm{R} 12$ & $\begin{array}{l}\text { United } \\
\text { States }\end{array}$ & $\begin{array}{l}\text { Blockchain, cybersecurity, digital } \\
\text { identity and e-residency }\end{array}$ & Academia & Greater than 20 years \\
\hline
\end{tabular}

\section{References}

1. Population Reference Bureau. World Population Data (International Data Indicators). Available online: https://www.prb.org/ international/ (accessed on 3 February 2022).

2. Kamolov, S.; Stepnov, I. Sustainability through digitalization: European strategy. E3S Web Conf. 2020, 208, 03048. [CrossRef]

3. Holroyd, C. Technological innovation and building a 'super smart' society: Japan's vision of society 5.0. J. Asian Public Policy 2022, 15, 18-31. [CrossRef]

4. Mavrodieva, A.V.; Shaw, R. Disaster and Climate Change Issues in Japan's Society 5.0—A Discussion. Sustainability 2020, $12,1893$. [CrossRef]

5. Chia, E.S. Singapore's smart nation program-Enablers and challenges. In Proceedings of the 11th System of Systems Engineering Conference (SoSE), Kongsberg, Norway, 12-16 June 2016.

6. Hoe, S.L. Defining a smart nation: The case of Singapore. J. Inf. Commun. Ethics Soc. 2016, 14, 323-333. [CrossRef]

7. Sá, M.; Santos, A.; Serpa, S.; Ferreira, C. Digital Literacy in Digital Society 5.0: Some Challenges. Acad. J. Interdiscip. Stud. 2021, 10, 1. [CrossRef]

8. Potočan, V.; Mulej, M.; Nedelko, Z. Society 5.0: Balancing of Industry 4.0, economic advancement and social problems. Kybernetes 2021, 50, 794-811. [CrossRef]

9. Nair, M.M.; Tyagi, A.K.; Sreenath, N. The future with industry 4.0 at the core of society 5.0: Open issues, future opportunities and challenges. In Proceedings of the International Conference on Computer Communication and Informatics (ICCCI), Coimbatore, India, 27-29 January 2021.

10. Aldabbas, M.; Xie, X.; Teufel, B.; Teufel, S. Future security challenges for smart societies: Overview from technical and societal perspectives. In Proceedings of the International Conference on Smart Grid and Clean Energy Technologies (ICSGCE), Kuching, Malaysia, 4-7 October 2020

11. Gurjanov, D.; Zakoldaev, A.; Shukalov, I.O.; Zharinov. The smart city technology in the super-intellectual Society 5.0. J. Phys. Conf. Ser. 2020, 1679, 032029. [CrossRef]

12. De Azambuja, L.S.; Pereira, G.V.; Krimmer, R. Clearing the existing fog over the smart sustainable city concept. In Proceedings of the 13th International Conference on Theory and Practice of Electronic Governance, Athens, Greece, 23-25 September 2020.

13. Orecchini, F.; Santiangeli, A.; Zuccari, F.; Pieroni, A.; Suppa, T. Blockchain Technology in Smart City: A New Opportunity for Smart Environment and Smart Mobility. In Intelligent Computing \& Optimization, ICO 2018. Advances in Intelligent Systems and Computing; Vasant, P., Zelinka, I., Weber, G.W., Eds.; Springer: Cham, Switzerland, 2019; Volume 866, pp. 346-354. [CrossRef]

14. Sharifi, A. critical review of selected smart city assessment tools and indicator sets. J. Clean. Prod. 2019, 233, 1269-1283. [CrossRef] 
15. Vasudavan, H.; Balakrishnan, S. The taxonomy of smart city core factors. In Proceedings of the 2019 7th International Conference on Information Technology: IoT and Smart City, Shanghai, China, 20-23 December 2019.

16. Georgiou, J.G.; Nell, A.I. Kokkinaki, Blockchain for smart cities: A systematic literature review. In Information Systems. EMCIS 2020. Lecture Notes in Business Information Processing; Themistocleous, M., Papadaki, M., Kamal, M.M., Eds.; Springer: Cham, Switzerland, 2020. [CrossRef]

17. $\mathrm{Li}, \mathrm{S}$. Application of blockchain technology in smart City infrastructure. In Proceedings of the IEEE International Conference on Smart Internet of Things (SmartIoT), Xi'an, China, 17-19 August 2018.

18. Mukherjee, P.; Barik, R.K.; Pradhan, C. A Comprehensive proposal for blockchain-oriented smart city. In Security and Privacy Applications for Smart City Development. Studies in Systems, Decision and Control; Tamane, S.C., Dey, N., Hassanien, A.E., Eds.; Springer: Cham, Switzerland, 2021; Volume 308, pp. 55-87. [CrossRef]

19. Rivera, R.; Robledo, J.G.; Larios, V.M.; Avalos, J.M. How digital identity on blockchain can contribute in a smart city environment. In Proceedings of the International Smart Cities Conference (ISC2), Wuxi, China, 14-17 September 2017.

20. Wong, P.F.; Chia, F.C.; Kiu, M.S.; Lou, E.C.W. The potential of integrating blockchain technology into smart sustainable city development. IOP Conf. Ser. Earth Environ. Sci. 2020, 463, 012020. [CrossRef]

21. MD World Competitiveness Center. Smart City Index 2021; IMD—International Institute for Management Development: Lausanne, Switzerland, 28 October 2021.

22. Kar, A.K.; Ilavarasan, V.; Gupta, M.P.; Janssen, M.; Kothari, R. Moving beyond smart cities: Digital nations for social innovation \& sustainability. Inf. Syst. Front. 2019, 21, 495-501. [CrossRef]

23. Nagy, K.; Hajrizi, E. Building pillars for adapting society 5.0 in post-conflict countries. IFAC-PapersOnLine 2019, 52, 40-45. [CrossRef]

24. Arief, A.; Sensuse, D.I. Designing A conceptual model for smart government in Indonesia using Delphi 2nd round validity. In Proceedings of the 2018 International Conference on Advanced Computer Science and Information Systems (ICACSIS), Yogyakarta, Indonesia, 27-28 October 2018.

25. De Haes, S.; Van Grembergen, W. An exploratory study into IT governance implementations and its impact on business/IT alignment. Inf. Syst. Manag. 2009, 26, 123-137. [CrossRef]

26. Hsu, C.-C.; Sandford, B. The Delphi Technique: Making Sense of Consensus. Pract. Assess. Res. Eval. 2007, 12, 10. [CrossRef]

27. Kluge, U.; Ringbeck, J.; Spinler, S. Door-to-door travel in 2035-A Delphi study. Technol. Forecast. Soc. Change 2020, 157, 120096. [CrossRef]

28. Melander, L.; Dubois, A.; Hedvall, K.; Lind, F. Future goods transport in Sweden 2050: Using a Delphi-based scenario analysis. Technol. Forecast. Soc. Change 2019, 138, 178-189. [CrossRef]

29. Schmalz, U.; Spinler, S.; Ringbeck, J. Lessons Learned from a Two-Round Delphi-based Scenario Study. MethodsX 2021, 8, 101179. [CrossRef]

30. Thangaratinam, S.; Redman, C.W.E. The Delphi technique. Obstet. Gynecol. 2011, 7, 120-125. [CrossRef]

31. Aghimien, D.; Aigbavboa, C.; Thwala, W.; Ohiomah, I. Challenges hindering the attainment of smart cities. Proc. Int. Struct. 2019, 6, 20-25. [CrossRef]

32. Rana, N.P.; Luthra, S.; Mangla, S.K.; Islam, R.; Roderick, S.; Dwivedi, Y.K. Barriers to the development of smart cities in indian context. Inf. Syst. Front. 2019, 21, 503-525. [CrossRef]

33. Bifulco, F.; Tregua, M.; Amitrano, C.C.; D'Auria, A. ICT and sustainability in smart cities management. Int. J. Public Sect. Manag. 2016, 29, 132-147. [CrossRef]

34. Aghimien, D.O.; Aigbavboa, C.; Edwards, D.J.; Mahamadu, A.-M.; Olomolaiye, P.; Nash, H.; Onyia, M. A fuzzy synthetic evaluation of the challenges of smart city development in developing countries. Smart Sustain. Built Environ. 2020. ahead-of-print. [CrossRef]

35. Ali, M.A.; Hoque, M.R.; Alam, K. An empirical investigation of the relationship between e-government development and the digital economy: The case of Asian countries. J. Knowl. Manag. 2018, 22, 1176-1200. [CrossRef]

36. Glyptis, L.; Christofi, M.; Vrontis, D.; Giudice, M.D.; Dimitriou, S.; Michael, P. E-Government implementation challenges in small countries: The project manager's perspective. Technol. Forecast. Soc. Change 2020, 152, 119880. [CrossRef]

37. Joshi, S.; Saxena, S.; Godbole, T. Shreya Developing smart cities: An integrated framework. Procedia Comput. Sci. 2016, 93, 902-909. [CrossRef]

38. Silva, B.N.; Khan, M.; Han, K. Towards sustainable smart cities: A review of trends, architectures, components, and open challenges in smart cities. Sustain. Cities Soc. 2018, 38, 697-713. [CrossRef]

39. Penmetsa, M.K.; Bruque, S. A framework for building a sustainable digital nation: Essential elements and challenges. Digit. Policy Regul. Gov. 2021, 23, 262-286. [CrossRef]

40. Singh, H.; Grover, P.; Kar, A.K.; Ilavarasan, P.V. Review of performance assessment frameworks of e-government projects. Transform. Gov. People Process Policy 2020, 14, 31-64. [CrossRef]

41. Tonggiroh, M. Digital government services in Papua. In Proceedings of the Second International Conference on Informatics and Computing (ICIC), Jayapura, Indonesia, 1-3 November 2017.

42. Weerakkody, V.; El-Haddadeh, R.; Al-Shafi, S. Exploring the complexities of e-government implementation and diffusion in a developing country. J. Enterp. Inf. Manag. 2011, 24, 172-196. [CrossRef]

43. Capdevila, I.; Zarlenga, M.I. Smart city or smart citizens? The Barcelona case. J. Strategy Manag. 2015, 8, 266-282. [CrossRef] 
44. Lenk, U. Smart cities and MBSE: Comparison of concepts. In Proceedings of the IEEE 15th International Conference of System of Systems Engineering (SoSE), Budapest, Hungary, 2-4 June 2020.

45. Sahib-Kaudeer, N.G.; Jhummun, D.S.; Gobin-Rahimbux, B. What is 'Smart' for small island developing states? In Proceedings of the IEEE International Conference on Emerging Technologies and Innovative Business Practices for the Transformation of Societies (EmergiTech), Balaclava, Mauritius, 1-6 August 2016.

46. Paul, M.; Upadhyay, P.; Dwivedi, Y.K. Roadmap to digitalisation of an emerging economy: A viewpoint. Transform. Gov. People Process Policy 2020, 14, 401-415. [CrossRef]

47. Zakzak, L. Citizen-centric smart city development: The case of smart Dubai's "Happiness agenda". In Proceedings of the 20th Annual International Conference on Digital Government Research, Dubai, United Arab Emirates, 18-20 June 2019.

48. Nahavandi, S. Industry 5.0-A human-centric solution. Sustainability 2019, 11, 4371. [CrossRef]

49. Zengin, Y.; Naktiyok, S.; Kaygın, E.; Kavak, O.; Topçuoğlu, E. An Investigation upon Industry 4.0 and Society 5.0 within the Context of Sustainable Development Goals. Sustainability 2021, 13, 2682. [CrossRef]

50. Ambira, C.M.; Kemoni, H.N.; Ngulube, P. A framework for electronic records management in support of e-government in Kenya. Rec. Manag. J. 2019, 29, 305-319. [CrossRef]

51. Samsor, A.M. Challenges and prospects of e-Government implementation in Afghanistan. Int. Trade Politics Dev. 2021, 5, 51-70. [CrossRef]

52. Ray, P.P. Digital India: Perspective, challenges and future direction. In Proceedings of the International Conference on Power, Signals, Control and Computation (EPSCICON), Thrissur, India, 6-10 January 2018.

53. Nasution, A.A.; Nasution, F.N.; Risanty, R. Smart city development strategy and it's challenges for city. IOP Conf. Ser. Earth Environ. Sci. 2020, 562, 012012. [CrossRef]

54. Meiyanti, R.; Utomo, B.; Sensuse, D.I.; Wahyuni, R. e-Government challenges in developing Countries: A literature review. In Proceedings of the 6th International Conference on Cyber and IT Service Management (CITSM), Parapat, Indonesia, 7-9 August 2018.

55. Shiroishi, Y.; Uchiyama, K.; Suzuki, N. Society 5.0: For Human Security and Well-Being. Computer 2018, 51, 91-95. [CrossRef]

56. Deng, H.; Karunasena, K.; Xu, W. Evaluating the performance of e-government in developing countries. Internet Res. 2018, 28, 169-190. [CrossRef]

57. Gladkova, M. Ragnedda Exploring digital inequalities in Russia: An interregional comparative analysis. Online Inf. Rev. 2020, 44, 767-786. [CrossRef]

58. Masinde, M.; Mkhonto, M. The critical success factors for e-Government implementation in South Africa's local government: Factoring in apartheid digital divide. In Proceedings of the IEEE 2nd International Conference on Information and Computer Technologies (ICICT), Kahului, HI, USA, 14-17 March 2019.

59. Shin, S.-C.; Ho, J.-W.; Pak, V.Y. Digital transformation through e-Government innovation in Uzbekistan. In Proceedings of the 22nd International Conference on Advanced Communication Technology (ICACT), PyeongChang, Korea, 16-19 February 2020.

60. Tan, S.; Taeihagh, A. Smart city governance in developing countries: A systematic literature review. Sustainability 2020, 12, 899. [CrossRef]

61. El-Kholei, A.O.; Yassine, G. The mirage of smart sustainable cities in the Arab region. Open House Int. 2019, 44, 8-16. [CrossRef]

62. Sarfraz, Z.; Sarfraz, A.; Iftikar, H.M.; Akhund, R. Is COVID-19 pushing us to the Fifth Industrial Revolution (Society 5.0)? Pak. J. Med. Sci. 2021, 37, 591-594. [CrossRef] [PubMed]

63. Apriliyanti, I.D.; Kusumasari, B.; Pramusinto, A.; Setianto, W.A. Digital divide in ASEAN member states: Analyzing the critical factors for successful e-government programs. Online Inf. Rev. 2020. ahead-of-print. [CrossRef]

64. Osifo, O.C. Examining digital government and public service provision: The case of Finland. In Proceedings of the 41st International Convention on Information and Communication Technology, Electronics and Microelectronics (MIPRO), Opatija, Croatia, 21-25 May 2018.

65. Saini, D.K.; Sandhiyaa, B.Y. Smart city and challenges. In Information and Communication Technology for Sustainable Development, Advances in Intelligent Systems and Computing; Tuba, M., Akashe, S., Joshi, A., Eds.; Springer: Singapore, 2020; Volume 933, pp. 643-649. [CrossRef]

66. Demir, K.A.; Döven, G.; Sezen, B. Industry 5.0 and human-robot co-working. Procedia Comput. Sci. 2019, 158, 688-695. [CrossRef]

67. Oni, S.; Berepubo, K.A.; Oni, A.A.; Joshua, S. E-Government and the challenge of cybercrime in Nigeria. In Proceedings of the Sixth International Conference on eDemocracy \& eGovernment (ICEDEG), Quito, Ecuador, 24-26 April 2019.

68. Jo, J.H.; Sharma, P.K.; Sicato, J.C.S.; Park, J.H. Emerging technologies for sustainable smart city network security: Issues, challenges, and countermeasures. J. Inf. Process. Syst. 2019, 15, 765-784. [CrossRef]

69. Farid, A.M.; Alshareef, M.; Badhesha, P.S.; Boccaletti, C.; Cacho, N.A.A.; Carlier, C.-I.; Corriveau, A.; Khayal, I.; Liner, B.; Martins, J.S.B.; et al. Smart city drivers and challenges in urban-mobility, health-Care, and interdependent infrastructure systems. IEEE Potentials 2021, 40, 11-16. [CrossRef]

70. Sulistya, Q.W.; Sulistiyo, B.B.; Aditya, F.; Aritonang, I.D.; Simangunsong, S.A.; Shihab, M.R.; Ranti, B. A case study of Indonesian government digital transformation: Improving public service quality through E-government implementation. In Proceedings of the 5th International Conference on Science and Technology (ICST), Yogyakarta, Indonesia, 30-31 July 2019.

71. Chauhan, S.; Agarwal, N.; Kar, A.K. Addressing big data challenges in smart cities: A systematic literature review. Info 2016, 18, 73-90. [CrossRef] 
72. Khan, H.H.; Malik, M.N.; Zafar, R.; Goni, F.A.; Chofreh, A.G.; Klemeš, J.J.; Alotaibi, Y. Challenges for sustainable smart city development: A conceptual framework. Sustain. Dev. 2020, 28, 1507-1518. [CrossRef]

73. Kwak, Y.H.; Lee, J. Evolution of korean smart city programs: Challenges and opportunities. In Proceedings of the 2020 IEEE Technology \& Engineering Management Conference (TEMSCON), Novi, MI, USA, 3-6 June 2020. 